\title{
Cash Crops, Print Technologies, and the Politicization of Ethnicity in Africa
}

\author{
YANNICK I. PENGL ETH Zürich, Switzerland \\ PHILIP ROESSLER William \& Mary, United States \\ VALERIA RUEDA University of Nottingham, United Kingdom
}

$W$

hat are the origins of the ethnic landscapes in contemporary states? Drawing on a preregistered research design, we test the influence of dual socioeconomic revolutions that spread throughout Africa during the nineteenth and twentieth centuries - export agriculture and print technologies. We argue these changes transformed ethnicity via their effects on politicization and boundary-making. Print technologies strengthened imagined communities, leading to more salient-yet porous-ethnic identities. Cash crop endowments increased groups' mobilizational potential but with more exclusionary boundaries to control agricultural rents. Using historical data on cash crops and African language publications, we find that groups exposed to these historical forces are more likely to be politically relevant in the postindependence period, and their members report more salient ethnic identities. We observe heterogenous effects on boundary-making as measured by interethnic marriage; relative to cash crops, printing fostered greater openness to assimilate linguistically related outsiders. Our findings illuminate not only the historical sources of ethnic politicization but also mechanisms shaping boundary formation.

\section{INTRODUCTION}

W hat are the origins of the ethnopolitical landscapes that shape contemporary states? A voluminous literature points to the influence that ethnicity - social identity based on shared descent and culture-has on politics and the allocation of state resources. From the provision of public services to civil war, ethnicity is found to structure a wide range of political and economic processes (Chandra 2004; Habyarimana et al. 2009; Horowitz 1985; Roessler 2016). In this paper we address the question of what drives ethnic politicization-that is, why politics revolves around some cultural groups and not others. Despite a rich qualitative and historical literature on the topic (Bates 1983; Posner 2005; Vail 1989a), quantitative studies typically do not engage the endogenous sources of ethnopolitical divisions that shape policy outcomes. This represents an important limitation, as inferences on the consequences of ethnic politics may be vulnerable to selection problems (Birnir et al. 2015; 2018).

\footnotetext{
Yannick I. Pengl (D), Postdoctoral Researcher, International Conflict Research, Department of Humanities, Social and Political Sciences, ETH Zürich, Switzerland, yannick.pengl@icr.gess.ethz.ch.

Philip Roessler (iD, Associate Professor, Department of Government, William \& Mary, United States, proessler@wm.edu.

Valeria Rueda (D), Assistant Professor, Department of Economics, University of Nottingham, United Kingdom, valeria.rueda@ nottingham.ac.uk
}

Received: August 11, 2020; revised: March 20, 2021; accepted: June 25, 2021. First published online: August 27, 2021.

\footnotetext{
${ }^{1}$ Across the ethnic politics literature, many studies model competition for power and resources among a given subset of politically relevant ethnic groups.
}

We seek to advance knowledge on this question, reporting the results of a preregistered research design. ${ }^{2}$ We distinguish between two interrelated processes that shape ethnic politics: boundary-making and politicization. The former - the sine qua non of ethnicity (Barth 1969)-encapsulates the social boundaries that regulate group membership and shape inter-ethnic ties. Following from Weber (1978) and others (Caselli and Coleman 2013; Fearon 1999; Parkin 1974; Wimmer 2013), we conceive of the porosity of group boundaries as being especially consequential for ethnic politics. Politicization, on the other hand, occurs when members of a cultural group coordinate on their shared identity to compete for state power (Bates 1983; Fearon 1999). In accounting for variation in boundary-making and politicization, our framework focuses on periods of significant material and cultural change that potentially strengthened groups' mobilizational capabilities and redefined the markers of group membership.

We study these phenomena across countries in Africa, a region in which ethnicity has structured political competition, but only among a subset of ethno-

\footnotetext{
${ }^{2}$ We preregistered our research design with Evidence in Governance and Politics (EGAP) on April 24, 2019, after some promising preliminary analyses but before merging our publications and cash crop data with Ethnologue language categories and group polygons and, via Ethnologue, to EPR, PREG, Afrobarometer, and DHS. We had already seen geographic correlations between cash crop locations and Afrobarometer/DHS outcomes as well as between proximity to missionary printing presses and Afrobarometer identity salience. However, we were in no position to analyze group-level outcomes, the actual publications treatment, or the ethnic specifications described below, as all of these require ethnic matches. Our preanalysis plan can be found here: https://osf.io/nqp2u.
} 
linguistic groups. ${ }^{3}$ Much existing scholarship on the politicization of ethnicity in Africa points either to the lasting effects of colonialism-via the arbitrary territorial partition of the continent to the imposition of indirect rule (Asiwaju 1984; Ekeh 1990; Englebert, Tarango, and Carter 2002; Mamdani 1996) - or to the role of contemporary political competition (Posner 2005). These factors are no doubt important but arguably too widespread to explain significant withincountry variation in ethnic identity salience (Vail 1989a). In addition, colonialism was embedded in larger socioeconomic changes. Two of particular importance were the cash crop revolution and the spread of Christianity by missionaries. Both of these transformations preceded the "Scramble for Africa" and may have affected ethnic identities independently of or in interaction with colonial policy making. We argue that these fundamental changes have path-dependent effects on contemporary ethnic mobilization and coalition formation despite significant institutional change over the last 150 years.

First, we posit that both the spread of cash crops and Christian missions contributed to the politicization of ethnicity. We hypothesized the transition to commercial export agriculture increased the ethnic politicization of groups endowed with cash crops through a resource channel that bolstered these groups' mobilizational capabilities but also via competition for land and the enforcement of descent-based property rights regimes. While missionaries also brought about important material changes through investments in new infrastructure and provision of education, perhaps even more important was the communication revolution they unleashed. Intent on spreading the Gospel, missionaries invested heavily in standardizing, writing and printing what were primarily oral languages. This improved treated groups' communication capabilities, while increasing ethnic salience through the strengthening of "imagined communities" (Anderson 1983) as the adoption of a standardized language and the consumption of a uniform set of cultural characteristics, texts, and histories enhanced group solidarity.

Even as these dual socioeconomic forces increased ethnic politicization, we hypothesized they differently reshaped ethnic boundaries. The "imagined communities" reconstructed through language standardization created an opportunity for the assimilation of outsiders through language and cultural immersionleaving a legacy of more inclusionary ethnic boundaries. Cash crop agriculture had a very different effect, as it was tied to control of the land. In the face of growing demand for access to their agricultural homeland, local communities employed ethnicity as a means of "social closure" (Parkin 1974; Weber 1978) to regulate land ownership and control agricultural rents-leaving a legacy of more exclusionary ethnic boundaries. ${ }^{4}$

To test these hypotheses, we combine detailed historical data on cash crop production and the diffusion of print and writing technology (as measured by publications in African languages) with contemporary ethnicity data. Our cash crop data is based on a comprehensive historical map on the source locations of exports in late colonial Africa created by Hance, Kotschar, and Peterec (1961) and digitized by Roessler et al. (2020). To measure language standardization and its dissemination through printing, we compile a novel dataset of historical African language publications from Rowling and Wilson (1923) and Mann and Sanders (1994). Together, these two bibliographic sources cover approximately 10,000 titles in 370 distinct African languages.

We employ group-level and individual-level indicators to measure ethnic politicization. At the group level, we use the Ethnic Power Relations (EPR; Vogt et al. 2015) and the Politically Relevant Ethnic Groups (PREG) datasets (Posner 2004a) to measure which ethnic groups or coalitions have been active in competition for state power during the postindependence period. At the individual level, we use Afrobarometer Rounds 3-6 that include a question on whether respondents self-identify more in ethnic or national terms. To analyze the hypothesized heterogeneous legacies of cash crops and print technologies on boundary-making and social closure, we employ a behavioral measure of ethnic assimilation: inter- and intraethnic marriages from a large sample of couples surveyed by USAID's Demographic and Health Surveys.

We use linguistic groups identified in the Ethnologue database as our primary unit of analysis to minimize concerns about endogenous sample selection (Laitin 2000a, 142). This enables us to merge our cash crop, publishing, and outcome data, along with a host of control variables, to the Ethnologue groups through spatial overlays or ethnic name matching. ${ }^{5}$ In the survey-based analyses, we use two types of specifications. The first-geographic models - are based on the location of individuals and the Ethnologue polygons in which they reside. These models compare people located in different places with and without historical cash crop production and/or missionary publishing. The second-ethnic models-are based on survey respondents' affiliation to a given ethnic group rather than place of residence. Thus, they compare individuals residing in the same location but from ethnic groups with differential exposure to historical cash crop production and missionary publishing. This enables separating culturally transmitted attitudes and behaviors from locational effects.

\footnotetext{
${ }^{3}$ In our sample of 35 sub-Saharan African countries, there exist 2,303 Ethnologue languages, whereas the Ethnic Power Relations dataset counts 140 groups relevant in the first year that countries in the region enter the dataset and another 158 groups relevant through its last year (Vogt et al. 2015).
}

\footnotetext{
${ }^{4}$ See Caselli and Coleman (2013) for a formalization of the link between social closure and ethnicity.

${ }^{5}$ For combining Ethnologue groups with information from EPR, PREG, DHS, and Afrobarometer, we use the publicly available ethnic links coded by Müller-Crepon, Pengl, and Bormann (2020).
} 
We employ three main methods to mitigate endogeneity concerns. First, we employ location fixed effects in our ethnic-level specifications to address mission selection into areas with favorable locational fundamentals or those populated by already large and more powerful groups. Second, we use our Africanlanguage publishing data to analyze the effects of print technologies at the intensive margin (i.e., estimating the effects of the magnitude of publication records among groups with at least one publication). Third, we instrument actual crop production with agroclimatic suitability to address the potentially endogenous uptake of commercial agriculture. We also conduct additional robustness checks to rule out alternative explanations such as the effects of group size, precolonial centralization, indirect rule, ethnic diversity, and conversion to Christianity.

We find that groups historically exposed to cash crops or print technologies are significantly more likely to be politically relevant after independence. According to PREG (EPR), groups that cultivated at least one of five major cash crops through the end of colonialism or with a historical publication in their language are, respectively, $129 \%(54 \%)$ and $88 \%$ (45\%) more likely than the average group to be politically relevant. These results are robust to instrumenting crops with suitability and when focusing only on the subsample of groups exposed to Christian missions.

At the individual level, we find that citizens residing in areas of historical cash crop production or living in Ethnologue polygons with a history of publishing are significantly more likely to self-identify with their ethnic group rather than nationality. Moreover, ethnic salience follows our expectation of cash crops producing location-specific effects among "stayers" and publishing producing broader cultural effects, including among "movers" (i.e., respondents living outside their ancestral ethnic homeland). We do not find evidence, however, that groups treated with cash crops or print technologies have more homogeneous political preferences today.

We find strikingly different effects of cash crops and publishing on the porosity of ethnic boundaries, as measured by observed interethnic marriage rates. Consistent with our expectation that cash crops engendered social closure and less openness to ethnic outsiders, we find interethnic marriage to be significantly lower even with linguistically closely related groups. In contrast, and consistent with the hypothesis that print technologies led to salient but more porous ethnic boundaries, we find null and sometimes positive effects on interethnic marriage with linguistically close ethnic outsiders but negative effects on marriages across large linguistic distances. However, in contrast to our expectations, both exposure to cash crops and print technologies are positively associated with contemporary ethnic-based conflict-suggesting that, even as print technologies opened the door to assimilation of culturally proximate outsiders, its politicizing effects ensured these groups have not escaped cycles of ethnic conflict.

Our findings address different research streams in the social sciences. Despite a strong consensus on the constructivist nature of ethnicity (Chandra 2012; Laitin and Posner 2001), the endogenous sources of ethnogenesis remain understudied. Our paper illuminates the historical role of export agriculture and publishing in Africa. Moreover, our analysis sheds light on the relationship between ethnic politicization and boundarymaking (Wimmer 2013). It is generally assumed that these two processes are reinforcing, leading perhaps to convergence in the types of social boundaries regulating politically relevant ethnic groups. This may or may not be the case; as we illustrate, even across politicized groups, boundary policing can vary based on pathdependent effects of material and cultural changes on assimilationist practices and norms of openness.

In advancing this line of inquiry, we draw on classic theories of group formation - Weber's (1978) notion of social closure, Anderson's (1983, 46-7, 7) framework on the ethnonational effects of print technologies, and prominent but conflicting accounts of how economic change transforms ethnic identities (Bates 1974; Gellner 1983; Robinson 2014). To date, there have been few systematic tests of Anderson's "imagined communities" hypothesis. ${ }^{6}$ We find strong support for a link between print technologies, language standardization, and ethnonationalism in Africa. However, as we explain below, the mechanisms through which these processes reconstructed ethnic identity differed from those of nineteenth-century Europe where "print capitalism," bureaucratic "languages of power," and state-sponsored nation-building fostered national identities rather than the subnational identities that arose across Africa.

As far as "modernization" is concerned, our results are broadly in line with Bates's (1974) intuition that competition for economic benefits may deepen ethnic divisions. At the same time, our focus on cash crops produced by African smallholder farmers suggests that rural economic change was just as important as the urban dynamics prominently highlighted in the existing literature (Cohen 1969; Epstein 1958).

Finally, our paper employs a preregistered design to address growing concerns about publication bias and data mining for significant results in historical persistence studies. Beyond guarding against cherry-picking positive findings, preregistration encourages careful ex ante theorizing and hypotheses development. Preregistration does not preclude ex post modifications of the prespecified analyses, but it does necessitate transparency about any changes made. In this vein, we describe all prespecified hypotheses and analyses in Supplementary Information IV.

\section{THE DETERMINANTS OF AFRICA'S ETHNIC LANDSCAPE}

In this section we more fully advance our theoretical argument on the influence of the cash crop and print

\footnotetext{
${ }^{6}$ However, see Sasaki (2017), who focuses on the influence of the printing press in Europe on language standardization.
} 
revolutions on shaping Africa's modern ethnic landscape. Before addressing each in turn, we first situate our argument within the broader ethnicity scholarship.

\section{Ethnic Boundary-Making and Politicization}

We conceive of a country's ethnic landscape as shaped by two key processes: boundary-making and politicization. The former encompasses the construction and maintenance of social differences (Barth 1969) in which individuals employ "points of social reference," such as ascriptive, cultural, or other markers, to place themselves and others into groups to "order" the world (Hale 2004). Boundary-making helps to solidify social groups through the adoption of criteria for membership and their enforcement by in-group members (Wimmer 2013). Following from Weber (1978), we consider a group's closure or accessibility as one of the most important dimensions of boundary-making (Wimmer 2013). Politicization, on the other hand, entails members of a given group consciously or subconsciously leveraging their shared identity to coordinate their behavior to access political and economic benefits (Bates 1983; Fearon 2006).

Generally, boundary-making and ethnic politicization are theorized to be reinforcing. This is perhaps most starkly illuminated in the civil war literature in which conflict along ethnic lines contributes to the hardening of social boundaries (Fearon and Laitin 2000; Kalyvas 2008). Other forms of political competition, such as elections, are also found to increase ethnic salience (Eifert, Miguel, and Posner 2010; Oucho 2002) -although this does not necessarily translate into higher degrees of closure. ${ }^{7}$ The reverse - that boundary-making facilitates ethnic politicization-is an important assumption in rationalist accounts of ethnic coalition formation that stress the need to exclude outsiders from the returns to collective action (Fearon 1999). ${ }^{8}$ The reinforcing effects of boundary-making and politicization may suggest some degree of convergence in the structure of social boundaries across politicized groups, but as far as we know this has not been empirically assessed. ${ }^{9}$

\section{Existing Literature}

What then explains boundary-making and politicization? Following from our conceptual framework, we expect factors shaping boundary-making to drive the

\footnotetext{
${ }^{7}$ Salience and closure capture different but potentially reinforcing identity dimensions. The former reflects the importance of an identity to oneself or others - i.e., the likelihood that a given identity and not others will be invoked across different situations (Stryker 1980). In contrast, closure reflects the degree to which a group is accessible to outside members (Wimmer 2013). Following from Stryker (1980), we might expect closed groups, in which entry and exit pose higher costs, to correlate with more salient identities.

${ }^{8}$ See also Bates (1983), Chandra (2006), and Posner (2017).

${ }^{9}$ We analyze this in Supplementary Information I. We find that politically relevant groups do tend to have less porous boundaries as measured by interethnic marriage, though these correlations are not particularly strong.
}

construction and enforcement of socially differentiated groups, whereas factors activating politicization likely work through their effects on group coordination and mobilization. Here we briefly synthesize existing research with a focus on sub-Saharan Africa.

Evolutionary and geographic approaches, respectively, attribute Africa's comparatively high ethnic diversity to the loss of genetic variation as human species migrated from the cradle of humankind (Ahlerup and Olsson 2012; van den Berghe 1981) and ecological variation, leading to economic and cultural differentiation (Michalopoulos 2012; Nettle 1998). What form these groups take and the degree of their politicization then depends on a host of historical, material, and institutional factors.

One factor regularly advanced as contributing to political relevance is group size, following the logic that a minimum support base is necessary to sustain viable political coalitions (Bates 1983; Posner 2004b; 2005). Beyond size, others point to the importance of groups sociopolitical structures, in particular legacies of centralized and hierarchical institutions (Michalopoulos and Papaioannou 2013). ${ }^{10}$ In the context of Africa's multiethnic states, historical statehood may have deepened ethnopolitical cleavages (Paine 2019).

Other research focuses on economic change and its differential effects on groups across the continent. Ekeh (1990), Nunn (2008), and Nunn and Wantchekon (2011) highlight how the slave trades contributed to ethnic fractionalization and strengthened norms of mistrust. The decline of the slave trades corresponded with the spread of export agriculture (Hopkins 1973) and Christian missionaries across the continent (Cagé and Rueda 2016). Bates (1974) mentions both of these factors as examples for spatially concentrated modernization benefits that spurred intergroup inequality, competition, and politicization. ${ }^{11}$ Other relevant economic changes include mining, railway construction, and perhaps most prominently urbanization (Cohen 1969; Horowitz 1985; Nnoli 1978; Vail 1989a).

Beyond their material effects, missionaries, export agriculture, and the colonial state had profound cultural effects. Through tracing the historical process, Ranger (1989) shows how missionary investments in the translation and printing of Bibles in vernacular languages "created rather than merely reflected" extant ethnolinguistic divisions. ${ }^{12}$ Berry (1993) and Lentz (2013) point to the effects of the commercialization of agriculture on the reconstruction of social

\footnotetext{
${ }^{10}$ Koter (2016), in contrast, argues that hierarchical institutions enabled postindependence rulers to target groups with patronagebased policies rather than ethnic appeals, potentially dampening ethnic salience. Also, Dunning and Harrison (2010) find that the historical legacy of cousinage from the Mali Empire has helped to weaken the political effects of ethnicity.

${ }^{11}$ For an illuminating ethnography on the interactive effects of Christian missionaries and cash crops on ethnic association formation, anticolonial resistance, and political mobilization, see Spear (1997). In the case of the Meru, ethnic mobilization contributed to the development of a broader nationalist movement (Okoth 2006).

${ }^{12}$ See also Chimhundu 1992; Posner 2003.
} 
identities, especially the distinction between "natives"-or "sons of the soil"-and "strangers" (Lentz 2013). Mamdani (1996) argues that the colonial project had much broader cultural effects through social engineering around the "customary." Reinforced through indirect rule and other colonial policies of social control (Eyoh 1999; Posner 2005), colonialism sharpened communal identities ${ }^{13}$ through ideologies of "tribalism" (Ekeh 1975) and "autochthony" (Lentz 2013). ${ }^{14}$

The anticolonial liberation struggle held the promise to reimagine social relations and national communities (Ake 1993; Ekeh 1990; Fanon 1963)-and in some cases, such as Nyerere's Tanzania, this was achieved (Miguel 2004). But largely, postcolonial competition for state power revolved around ethnopolitical networks, further deepening ethnic politicization (Horowitz 1985; Nnoli 1998; Roessler 2016; Rothchild 1997). The advent of multiparty elections with the end of the Cold War, in some cases, transformed ethnopolitical configurations (Posner 2005), but this often intensified rather than dampened ethnic salience (Eifert, Miguel, and Posner 2010; Oucho 2002) as well as autochthonous mobilization (Ceuppens and Geschiere 2005; Marshall-Fratani 2006). However, there is some evidence that urbanization and demographic change (leading to greater levels of ethnic diversity), as well as democratic institutions, are reducing ethnic favoritism (Burgess et al. 2015; Ichino and Nathan 2013; Kramon et al. 2021).

$$
* * *
$$

We build on and extend this literature by developing and systematically testing new hypotheses on how the cash crop and print revolutions shaped processes of ethnic boundary-making and politicization from the nineteenth century onward.

\section{The Cash Crop Revolution}

In the nineteenth and twentieth centuries, African economies underwent an important structural transformation away from the slave trades that dominated exchange for the previous four hundred years to commercial export agriculture (Frankema, Williamson, and Woltjer 2018; Hogendorn 1969; Hopkins 1973)..$^{15}$ The cash crop revolution led to an important spatial shift in economic production to areas suitable for oil palm, groundnuts, cocoa, coffee, and cotton and enabled millions of African smallholders and traders to benefit from global exchange (Hopkins 1973). Fueled by

\footnotetext{
${ }^{13}$ Colonial partition itself, however, may have contributed to stronger national identities among groups divided between two sovereign states (Miles and Rochefort 1991; Robinson 2014).

${ }^{14} \mathrm{On}$ the genealogy of autochthony and its roots in colonialism, see Ceuppens and Geschiere (2005); Marshall-Fratani (2006).

${ }^{15}$ Cash crops would prove a much more important source of colonial exports than minerals. By 1957, across the 35 countries in our dataset, cash crops accounted for $59.4 \%$ of total exports (by value) compared with only $22 \%$ for minerals (Hance, Kotschar, and Peterec 1961).
}

European-financed transportation infrastructure before and during colonialism, these cash crop zones were vertically integrated with export markets but with weak horizontal linkages with the rest of the colony (Hirschman 1977; Rodney 1972; Roessler et al. 2020).

Consistent with Bates (1974), we posit that the spatial disparities arising from the cash crop revolution had important path-dependent effects on ethnic politicization. The takeoff of export agriculture endowed some groups - those who would be the primary producers of cash crops or the owners of the land on which they were produced-with a common economic niche, much greater wealth potential than others, and clear incentives to defend these advantages in competition with other groups.

A second and closely related channel of ethnic politicization was via the effects of the commercialization of agriculture on land tenure regimes. ${ }^{16}$ Many of the most suitable areas experienced an increase in demand for land as waves of farmers, including enterprising migrant farmers (Hill 1963), adopted cash crops. Labor migration to cash crop areas further increased local diversity, land pressures, and intergroup competition.

The commercialization of agriculture combined with migration-led population growth induced important changes in the social bases of land tenure regimes. In precolonial Africa, land rights were contingent on group membership or allegiance to traditional authorities (Berry 1993). These practices did not change per se with the advent of cash crop agriculture and colonialism. What did, however, were outsiders' eligibility for group membership as ethnic boundaries became more tightly regulated (Boni 2006; Lentz 2013). Thus, following from Weber's (1978) idea of social closure (Parkin 1974), in which social identity is employed as a means of restricting access to economic rents, in the face of rising land values and an influx of migrants, ethnic boundaries were more firmly policed to exclude outsiders from land ownership. ${ }^{16}$ In line with the idea that ethnic differences are constructed, at least partially, as "a boundary-enforcement device" (Caselli and Coleman 2013, 162) to control private goods, contestation over land not only made ethnicity more salient; it likely led sons of the soil to emphasize less accessible criteria of group membership such as ascriptive characteristics and ancestral ties to the land. ${ }^{18}$ In a fascinating ethnography of the effects of the spread of cocoa and migrant farmers to the Sefwi homeland (located in present-day western Ghana) from the early twentieth century onward, Boni (2006) documents this

\footnotetext{
${ }^{16}$ For important previous work on the sociopolitical implications of the transition to commercial agriculture, see Colson (1971), Berry (1993), and Boone (2014; 2017).

${ }^{17}$ This process of ethnic boundary hardening was driven from below - as chiefs found themselves under growing pressure from their constituents not to give away too much land to outsiders (Boni 2006) - but also supported from above-as colonial governments promoted neocustomary land tenure regimes (Boone 2017; Mamdani 1996, 104-5).

${ }^{18}$ See also Bates $(1974,465-7)$ on how local elites in cash crop areas used ethnic criteria to restrict access to modernization benefits.
} 
precise dynamic unfolding-resulting in the "ancestralization of land rights" and more stringent enforcement to prevent migrants from permanently owning land.

We expect these mechanisms to only apply to regions of African smallholder production. Where European companies, settlers, or the colonial state dominated production, land alienation and labor coercion likely undercut local control of agricultural rents, weakened ethnic institutions, and reduced opportunities for ethnic boundary-making.

\section{Christian Missions, Print Technologies, and African Language Publications}

As the abolition of the slave trade ushered in cash crop agriculture in Africa, it also gave momentum to the spread of Christian missions across the continent. In their endeavor to spread the Gospel, missionaries spearheaded a communication revolution.

Missionaries translated the Bible and education materials into vernacular languages as a vehicle for conversion (Laitin 2007; Ranger 1989; Woodberry 2012). As most African languages were oral languages, missionaries first invested in language standardization and developing Latin-script writing systems (Posner 2003; Ranger 1989). To propagate language knowledge and consumption of the written texts, printing presses were imported to publish Bibles, hymnals, and grammar books that were then used in churches and schools (Cagé and Rueda 2016; Posner 2003). This communication revolution was most intense in British colonies given the preponderance of Protestant missionaries and the promotion of local languages and culture as part of indirect rule arrangements (Albaugh 2014). ${ }^{19}$

Anderson's (1983) argument on the influence of print capitalism on European nation-building is a valuable reference when considering the effects of Africa's print revolution on ethnonational communities. However, while language standardization and printing underpinned significant social changes in both regions, some mechanisms differed (Ranger 1989). First, given lower literacy and less integrated markets, in Africa the consolidation of ethnolinguistic consciousness and politicization did not result from the simultaneous mass consumption of newspapers and novels followed by state adoption and enforcement of national languages. Instead, missionary investments in language and printing in Africa instigated much more localized "imagined communities," which were constructed and sustained by new cultural entrepreneurs (initially indigenous missionaries undertaking the language standardization) and by community members' exposure to the translated Bibles, conversionary material, and other printed texts in vernacular languages. These activities spurred ethnonational "awakenings" similar to what Anderson $(1983,73)$ describes in Europe - where the

\footnotetext{
${ }^{19}$ In French colonies, educational instruction was mandated to be in French. Albaugh (2014) estimates that by 1950 only around 58\% of the population in French colonies had their languages transcribed compared with $76-81 \%$ in British, Belgian, and Portuguese colonies.
}

"energetic activities of ... professional intellectuals were central to the shaping of nineteenth-century European nationalisms." In Africa, an intelligentsia of mostly mission-educated linguists, writers, and teachers transmitted ideas of groupness through the churches and schools and, in turn, created new ethnic elites who further promoted the group's values and solidarity through literature, newspapers, and the formation of cultural associations (Vail 1989a, 11-2).

Another important difference with Europe was the role of the state. According to Anderson $(1983,76)$, the expansion of European states increased the importance of official languages and fostered the development of a bureaucratic middle class. At the same time, statesponsored nationalisms promoted linguistic assimilation and national identities (Weber 1976). In contrast, in colonial Africa, the state was run by Europeans with little interest in fostering an African class of bureaucrats. Instead, colonial authorities focused on thwarting rather than promoting any kind of national identity, fearing the rise of revolutionary movements (Vail 1989a).

The Yoruba represent a paradigmatic case of the influence of missionary language investments and publishing on the reconstruction of ethnic identity. ${ }^{20}$ With the collapse of the Oyo empire at the end of the eighteenth century, civil wars and slave raiding divided the Yoruba into rivalrous subgroups (Adediran 1984). From the 1840s onward, however, missionaries from the Church Missionary Society (CMS), including freed slaves, such as Samuel Crowther, contributed to the rebuilding of the Yoruba ethnic nation. Intent on spreading Christianity, the CMS missionaries worked on Yoruba orthography, translation, and publishing, even starting a Yoruba newspaper in as early as 1859 (Falola 1999). In propagating a standardized language and embracing and promoting the ethnonym "Yoruba," the Christian missionaries boosted Yoruba ethnic consciousness (Peel 2003). Moreover, as missionaries interpreted Yoruba history and tradition through a Christian lens (most famously Samuel Johnson in The History of the Yorubas), ethnogenesis and religious change reinforced each other. Consistent with Vail (1989b), missionary schools contributed to the propagation of standardized Yoruba through instruction in the language, which then produced new elites who served as champions of Yoruba solidarity and nationalism (Usman and Falola 2019). This is personified in the life of Obafemi Awolowo, one of Nigeria's founding fathers. Awolowo, born into one of the first Christian families in Ikenne, was educated in missionary schools before leading a pan-Yoruba cultural association (Egbé Omọ Odùduwà) dedicated to "reinventing a common Yorùbá identity" (Adebanwi 2014).

The standardization and printing of African languages is therefore expected to have strengthened groups' ethnonationalism and their mobilizational capabilities - with the rise of new ethnic elites and the

\footnotetext{
${ }^{20}$ For other case studies, see Ranger (1989), Chimhundu (1992), and Strommer (2015).
} 
writing and printing technologies they could wield as they competed in the political arena. In addition to strengthening groups' political capacity, the print revolution likely contributed to more expansionary identities than cash crop agriculture, as missionaries encouraged language uptake and provided opportunities for outsiders to learn the language via dissemination of language materials, church-related activities, and schooling. The upshot was the construction of more porous ethnic boundaries and assimilationist cultural practices-at least among those who adopted the group's language.

\section{HYPOTHESES}

Following from our theoretical framework, we preregistered the hypothesis that groups exposed to cash crops or print technologies are more likely to be politically relevant in the postindependence period. We also expected this to lead to more salient ethnic identities among individual group members. Despite these similar effects on ethnic politicization, we expected differential effects on boundary-making. We hypothesized that the commercialization of agriculture led to the construction of less porous ethnic boundaries than vernacular publishing and predicted lower rates of interethnic marriage for the cash crop than for the publication treatment. ${ }^{21}$

\section{DATA}

In this section we describe the various sets of data we assemble to test our hypotheses. We explain the use of Ethnologue to derive units of analysis, describe our historical data on cash crops and African language publishing, and discuss our proxies for ethnic politicization, salience, and boundary-making. ${ }^{22}$

\section{Historical and Geographic Data}

\section{Identifying Potentially Relevant Groups}

For a candidate list of nominal ethnic categories, we use Ethnologue, a reference source on living languages. Ethnologue attempts to capture the complete universe of languages regardless of their social or political relevance or demographic size (Simons and Fennig 2017). Having been compiled from the 1950s onward, Ethnologue may nevertheless miss a few precolonial small or extinct ethnolanguage groups. However, selection issues seem minimal in comparison with datasets like

\footnotetext{
${ }^{21} \mathrm{We}$ also preregistered a set of ancillary hypotheses and analysis on homogeneous political preferences, interethnic trust and ethnic conflict that we report in Supplementary Information IV.

${ }^{22}$ Data and replication scripts for all analyses in this article and the Online Appendix are openly available in the APSR Dataverse (Pengl, Roessler, and Rueda 2021). The replication folder also contains extended Supplementary Information with additional data descriptions and results.
}

AMAR, EPR, or Murdock (1959; 1967). ${ }^{23}$ Identifying potentially salient ethnic categories from Ethnologue restricts our focus to ethnolinguistic rather than racial, religious, or regional markers. The analytical consequences of this restriction are minimal since in our sub-Saharan African sample practically all ethnic categories in EPR, PREG, Afrobarometer, and DHS are equivalent to, or combinations of, language families, languages, or dialects. Another advantage of Ethnologue is that its companion dataset, the World Language Mapping System (WLMS) provides maps demarcating linguistic homelands, which we leverage to spatially aggregate our cash crop data, survey-based outcome measures, and geographic control variables as described in detail below.

\section{Cash Crops}

To measure cash crop production, we use a geospatial dataset on the primary commodity revolution in Africa from Roessler et al. (2020), drawing on a historical map produced by Hance, Kotschar, and Peterec (1961). The map depicts the source locations of more than $95 \%$ of exports in 1957 across 38 states in sub-Saharan Africa. ${ }^{24}$ Each primary commodity production point represents a value of $\$ 289,270$ in 1957 USD. The dataset covers nine groups of cash crops; ${ }^{25} 20$ minerals and metals; and forest, animal, and manufactured products.

Our main analysis focuses on the five main cash crops: cocoa, coffee, cotton, palm, and groundnut, representing $80 \%$ of total cash crop production and no less than half of all exports in 1957 across the countries in our sample. In addition, these five crops were predominantly produced by African smallholders rather than European settlers or on plantations, which makes them more relevant for our stipulated causal mechanism than other resources. Our Supplementary Information (section III.5) presents additional analyses also including other crops and minerals and more precisely coding the mode of production for all country-crop combinations in the Hance data. Figure 1 maps the 4,651 locations that produced one of the five most important export crops.

\section{Print Technologies and Publishing Data}

To capture exposure to print technologies, we draw on two library databases to construct a record of historical publishing at the language level. ${ }^{26}$ In combination with Ethnologue and WLMS, this represents the first ethnically linked and geocoded database of publishing in

\footnotetext{
${ }^{23}$ AMAR and EPR rely on some indication of social or political relevance as a basis for inclusion. Murdock $(1959 ; 1967)$ has a much smaller number of groups than Ethnologue. See Laitin (2000b, 142) on the advantages of using "language as a proxy for ethnicity."

${ }^{24}$ It excludes data on the Union of South Africa (including presentday Namibia), Madagascar, and other island colonies.

${ }^{25}$ Cocoa, coffee, cotton, groundnuts, oil palm, stimulants, other food crops, other industrial crops, other oils.

${ }^{26}$ This approach was inspired by Chaney's (2016) work on the Middle East.
} 


\section{FIGURE 1. Publications and Cash Crop Locations}

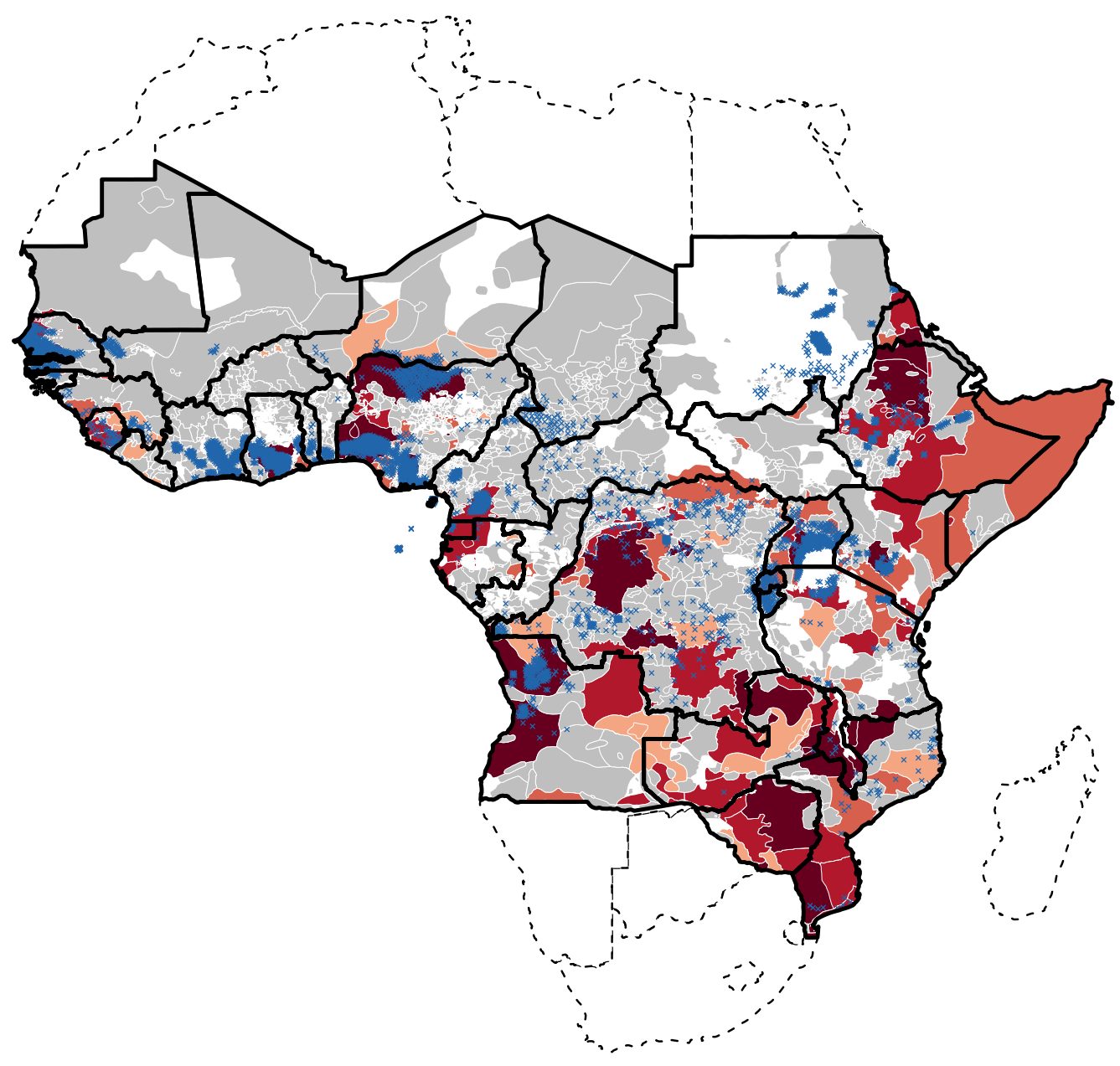

Cash Crop Production (1957)

Note: Language homelands are mapped according to Ethnologue. Grayed regions are Ethnologue polygons for which there is no record of publications. Colors indicate the number of publications listed in Rowling and Wilson (1923). Each blue cross locates 289,270 USD (1957) of cash crop export value for either cocoa, coffee, cotton, groundnuts, or palm oil. Solid black country borders describe our sample.

African languages throughout the colonial period and after independence.

The first source is a 1923 compilation of 2,480 publications across 168 languages (Rowling and Wilson 1923). It was intended to serve as a reference book for publications by Christian missionaries in Africa including not just religious texts but also dictionaries, grammar books, educational materials, and newspapers. It also provides contemporaneous estimates of the number of speakers per included language, which we use to normalize the number of publications.

Our second source (Mann and Sanders 1994) catalogues "collections of African language texts at SOAS, ... the African Department of SOAS, the International Institute for African Languages and Cultures, ... and the International Committee on Christian Literature for Africa." This source complements Rowling and Wilson (1923), especially given its greater temporal coverage. However, Mann and Sanders (1994) exclude grammars and dictionaries, which may have been particularly important for constructing salient ethnolinguistic communities. It is much less comprehensive on early printed materials, as it counts $50 \%$ fewer pre- 1925 titles than Rowling and Wilson (1923). We thus use Rowling and Wilson (1923) as the main source in our analysis and present results using Mann and Sanders (1994) in the Online Appendix.

The map in Figure 1 shows the total number of publications per ethnolinguistic polygon as listed in Rowling and Wilson (1923). 


\section{Contemporary Data on Ethnic Identities and Political Relevance}

We use several data sources to measure the main outcomes of our study: ethnic politicization and boundary-making at the group and individual level.

\section{Group-Level Politicization Measures}

To measure which Ethnologue groups serve as bases for contemporary political mobilization, we match Ethnologue to two expert-coded sources on ethnic groups' relevance in national-level political competition postindependence: the Politically Relevant Ethnic Groups (PREG; Posner 2004a) and the Ethnic Power Relations (EPR; Vogt et al. 2015) datasets. For each, we code a binary outcomes indicating whether the Ethnologue group has a one-to-one match in PREG/EPR (e.g., Yoruba and Yoruba) or is a clearly identifiable part of a broader ethnic coalition coded as relevant by the respective dataset (e.g., the Gikuyu language as part of the Kikuyu-Meru-Embu coalition in EPR). All Ethnologue groups without any plausible exclusive or coalition match to the respective dataset are coded zero on the respective PREG or EPR outcome. ${ }^{27}$

\section{Individual-Level Politicization Measures}

The salience of individual members' ethnicity vis-à-vis other identities likely varies between and within ethnic groups. To analyze this, we use survey data from rounds 3-6 of Afrobarometer, which ask respondents whether they identify more in ethnic or in national terms (Ali et al. 2019; Robinson 2014). We use a dummy variable of whether a respondent identifies more strongly or even only in ethnic rather than national terms as the outcome in our Afrobarometer specifications.

\section{Boundary-Making}

A key dimension of boundary-making is a group's accessibility to outsiders. Given the importance of marriage in social relations and group maintenance, many scholars view "endogamy [as] the ultimate measure of the salience of boundaries for intergroup relations" (Hechter 1978, 304). The underlying assumption is that groups with more exclusionary boundaries are less likely to marry outside their group-and to develop norms against such practices. To calculate ethnic exogamy, we use USAID's Demographic and Health Surveys (DHS) that includes data on the ethnicity of individuals and their spouses. These measures are described in more detail below.

\footnotetext{
${ }^{27}$ In robustness checks, we also use more restrictive versions and only code Ethnologue groups with exclusive one-to-one matches as 1 and all other groups as 0. Supplementary Information I.3 provides an intuitive example of this distinction and Appendix Figure A1 shows results. We also use AMAR (All Minorities at Risk) to measure groups' social relevance capturing group consciousness and shared norms and cultural features short of national-level political mobilization (Birnir et al. 2015,112). See Appendix Figure A2 for results.
}

\section{ANALYSIS I: ETHNIC POLITICIZATION AND SALIENCE}

We first report our specifications and results for the effect of cash crops and publishing on ethnic politicization at the group and individual levels.

\section{Group-Level Specification and Results}

To test for group-level effects, we estimate regression equation 1 using OLS.

$\operatorname{Pol}_{e c}=\beta_{0}+\beta_{1}$ CashCrops $_{e c}+\beta_{2}$ Publications $_{e c}+X_{e c}^{\prime} \gamma+\lambda_{c}+\varepsilon_{e c}$.

$\mathrm{Pol}_{e c}$ measures the political relevance of Ethnologue group $e$ in country $c$, using PREG or EPR. Cash Crops ${ }_{e c}$ is a binary measure of historical cash crop cultivation in the Ethnologue polygon. Publications $e_{e}$ indicates whether Rowling and Wilson (1923) lists at least one publication in Ethnologue language $e ; \lambda_{c}$ represents country fixed-effects; and $\boldsymbol{X}_{e c}^{\prime}$ is a set of standard geographic and historical controls including agricultural suitability; tsetse fly and malaria ecology; elevation; ruggedness; average yearly precipitation; average yearly temperature; distances (in logs) to the coast, to navigable rivers, to cities in 1900 , to the country capital, to historical missions, and to missionary printing presses; and absolute longitude and latitude.

Figure 2 reports the estimates of regression 1 when the outcome is a binary variable equal to one if the ethnic group is matched to a politically relevant group or coalition in PREG or EPR. Our baseline results indicate that, conditional on controls, a group with historical cash crop production is roughly $16-17$ percentage points more likely to be listed as politically relevant in PREG and EPR (a 129\% and 54\% increase from the sample mean of the dependent variable, respectively). Similarly, languages with historical publishing are 11-13 percentage points more likely to be listed as politically relevant in PREG and EPR (an $88 \%$ and $45 \%$ increase from the respective outcome mean).

Potential endogeneity necessitates caution in causally interpreting the correlations reported in Figure 2. One important concern is that our results are driven by geographic or historical determinants of ethnic groups' take-up of cash crops and print publishing. ${ }^{28}$ We employ several strategies to address this issue.

First, we instrument Cash Crops $e_{e c}$ with indicators of suitability for cash crop agriculture and estimate the effects using a spatial-2SLS (S2SLS) strategy, following Betz, Cook, and Hollenbach (2019). The instrument is the average agroclimatic suitability from the FAO GAEZ database across the five most important African cash crops (cocoa, coffee, cotton, groundnuts, and oil

\footnotetext{
${ }^{28}$ Figure I.9 in our Supplementary Information shows that groups with cash crops or publications systematically differ from those without on a number of baseline covariates.
} 


\section{FIGURE 2. Cash Crops, Print Technologies, and Political Relevance}

\section{Cash Crops, Publications \& Political Relevance \\ UoA: Ethnologue languages, DV: Any Match in PREG/EPR}

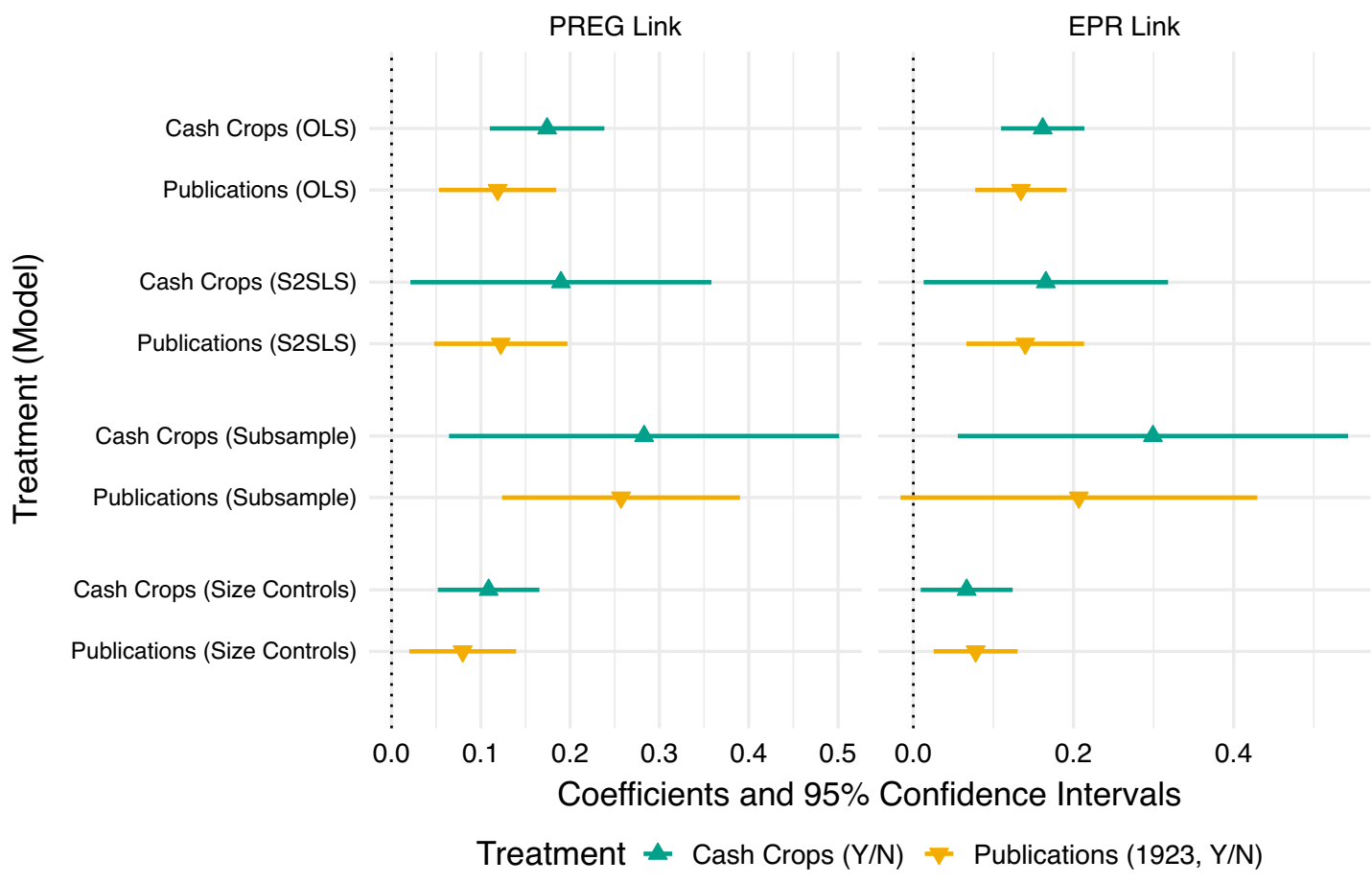

Note: These figures summarize the results of eight regression models. The two binary outcomes indicate whether an Ethnologue group is matched to a group or coalition listed as politically relevant in PREG (left-hand panel) or EPR (right-hand panel). Lines 1 and 2 report effects using binary treatments, indicating whether Ethnologue groups were exposed to cash crop production and/or print technologies. In lines 3 and 4, cash crops are instrumented with the mean agroclimatic suitability for the five most important export crops by using the spatial 2SLS approach described in the text. In lines 5 and 6 , the sample is restricted to Ethnologue polygons that experienced missionary activity. Lines 7 and 8 control for logged historical population per Ethnologue polygon based on HYDE raster data.

palm) in the homeland of ethnic group $e$. These suitability scores combine soil and climatic characteristics to predict the ecological potential to grow specific crops in rainfed agricultural systems. To serve as a valid instrument, suitability may only affect outcome variables through its influence on actual cash crop production. We argue that this exclusion restriction likely holds, conditional on the rich set of geographic and historical controls in our models, especially general agricultural suitability, temperature, and precipitation, which are included to isolate cash-crop-specific effects from overall agricultural productivity and its social and political consequences.

The suitability instrument strongly predicts colonial cash crop production in first-stage regressions. The first-stage $F$-statistic is 13.5 in the EPR and 13.3 in the PREG models. To account for potentially similar spatial patterns in the instrument and outcomes that may threaten the exclusion restriction, the IV models further include a spatial lag of the respective political relevance outcomes instrumented with first- and second-order spatial lags of the baseline controls (Betz, Cook, and Hollenbach 2019). All spatial lags are based on a binary contiguity matrix that defines ethnic group $e$ 's neighbors as all other ethnic polygons within a $100-\mathrm{km}$ centroid distance. ${ }^{29}$ Line 3 in Figure 2 shows that S2SLS results remain similar to baseline OLS although confidence intervals naturally become wider.

A second endogeneity concern is that European missions tended to establish outposts in geographically favorable areas or those with already more intensive colonial presence (Jedwab, zu Selhausen, and Moradi 2018). Subsetting the analysis to groups exposed to missions makes the analysis sample more comparable in terms of geographic fundamentals and other potential determinants of missionaries' targeting of specific groups and areas. The results, reported in line 6 of Figure 2 remain robust, despite the large reduction in observations and correspondingly large standard errors.

\footnotetext{
${ }^{29}$ The joint significance of spatially lagged baseline controls in the second first stage (predicting the spatially lagged dependent variable) is high, and the respective $F$ statistics remain well above conventional thresholds.
} 


\section{Individual-Level Specification and Results}

To test for individual-level effects, we use survey data of expressed ethnic salience and estimate the following equation in a geographic and an ethnic variant:

$$
\begin{gathered}
\operatorname{Sal}_{i e \ell c s}=\mu_{0}+\mu_{1} \text { Cash Crops }_{k c s}+\mu_{2} \text { Publications }_{k c s} \\
+W_{i \ell c s}^{\prime} \gamma+\eta_{k^{\prime}}+\varepsilon_{i e \ell c s .} \\
k \in\{e, \ell\}, \quad k^{\prime} \in\{\ell, c s\} .
\end{gathered}
$$

Sal $l_{\text {ielcs }}$ is a binary Afrobarometer-based survey measure of greater ethnic than national identification. The unit of analysis now is respondent $i$, who identifies with ethnic group $e$, residing in survey location $\ell$, in country $c$, and is interviewed in Afrobarometer survey round $s$. We assign Afrobarometer respondent $i$ to ethnic group $e$ based on the language they report speaking at home and use geographic information on Afrobarometer's survey locations $\ell$ to assign individual respondents to Ethnologue polygons.

In our geographic specifications $(k=\ell)$, we use the cash crop production value within a $15-\mathrm{km}$ radius of a survey location as treatment variable Cash Crops ${ }_{c c s}$. The variable Publications $\ell_{\ell s}$ is the number of publications in the language of the local Ethnologue polygon normalized by historical group population as provided in Rowling and Wilson (1923). The geographic specifications thus assign treatment variables entirely based on respondents' place of residence and irrespective of their self-reported ethnic identity. The ethnic specifications $(k=e)$, on the other hand, only use self-reported ethnic affiliation to assign treatments, regardless of individual locations. More specifically, for all members of group $e$ in country $c$ for survey $s$, Cash Crops ecs $_{\text {is }}$ the value of historical cash crop production per $\mathrm{km}^{2}$ in the ethnic polygon of $e$, and Publications $_{e c s}$ is the number of publications in the language of $e$, again normalized by population. ${ }^{30}$

Fixed effects $\eta$ are either at the country-round level (cs) for geographic specifications or at the survey location-level $(\ell)$ for ethnic specifications. The main motivation for these two specifications is to separate location-specific from culturally transmitted groupwide effects. Thus, the geographic specifications investigate whether respondents living in areas historically exposed to cash crop production and/or missionary publishing report more salient ethnic identities. The ethnic specifications examine whether members of historically exposed ethnic groups report salient identities, even when compared with respondents from other groups in the same location. Where not absorbed by location fixed effects, geographic and historical controls are the same as those stated in the previous section and always include an estimate of logged historical population from HYDE (Klein Goldewijk, Beusen, and Janssen, 2010). In all Afrobarometer analyses, we also control for individuallevel controls including gender, age, education levels, and indicators of standards of living.

\footnotetext{
${ }^{30}$ See Supplementary Information (Figure I.8) for a concrete example.
}

Table 1 reports the results of our geographic specifications. A one-standard-deviation increase in the value of cash crop production around location $\ell$ increases respondents' ethnic identification by around $1.1 \%$ of a standard deviation (approximately 0.4 percentage points or $3 \%$ of the outcome mean). Similarly, a one-standard-deviation increase in publications per capita increases ethnic identification by around $3.7 \%$ of a standard deviation (approximately 1.3 percentage points or $10 \%$ of the outcome mean). This effect is robust to intensive-margin comparisons (column 6). The effects are driven by ethnic stayers-individuals who reside in one of the Ethnologue polygons matched to their self-reported ethnic group $e$. Column 5 shows that restricting the analysis to ethnic leavers (those who reside outside of their ethnic group's homeland) results in a null effect of print technologies and a significant negative effect of cash crops.

The results of the ethnic specifications are reported in Table 2. Among individuals within the same survey location, ethnic salience is significantly higher among the ethnic groups with a history of publishing. A onestandard-deviation increase in publications per (estimated) thousand people increases respondents' ethnic identification by around $1.0 \%$ of a standard deviation (approximately 0.3 percentage points, or $2.4 \%$ of the mean outcome, see columns 2 and 3 ). In contrast, historical cash crop production now has no significant effect. ${ }^{31}$

Whereas cash crops increased ethnic salience only among stayers, publishing significantly elevates ethnic identities among movers (column 4). This cultural mover effect is robust to intensive margin-only comparisons (column 5). This suggests a culturally transmitted effect of print technologies - the formation of an "imagined community" - which persists even among migrants (or their descendants).

Overall, we find that ethnic groups with higher levels of historical cash crop production and publishing are more likely to be politically relevant in the postindependence period and that individuals from these groups report more politically salient ethnic identities. The individual-level ethnic salience results suggest we are capturing two different channels of politicization - one tied to place and the other stemming from cultural transmission. That these correlate, respectively, with localized cash crop production and vernacular publishing increase our confidence that these historical processes were at least part of the causal chain shaping ethnic politicization in Africa.

\footnotetext{
${ }^{31}$ These standardized effects are comparable or larger than other controls. For instance, $\widehat{\beta}_{2}$ in column 3 of Table 2 is six times larger than the absolute effect of a $10 \%$ increase in precolonial ethnic population and roughly $20 \%$ smaller than the effect of formal primary schooling. Appendix Table A1 compares our coefficients with individual-level proxies used by Robinson (2014). The effect of a onestandard-deviation change in our treatments of interest represent, across specifications, $20-56 \%$ of the effect of contemporary individual characteristics such as gender or formal employment. Also note that town fixed effects in Table 2 can aggravate attenuation bias (Aydemir and Borjas 2011).
} 
TABLE 1. Geographical Persistence in Ethnic Identity

\begin{tabular}{|c|c|c|c|c|c|c|}
\hline & \multicolumn{6}{|c|}{ Geographic-level: Ethnic vs. national identity } \\
\hline & (1) & $(2)$ & (3) & $(4)$ & $(5)$ & (6) \\
\hline $\begin{array}{l}\text { Cash crops, USD per } \\
\mathrm{km}^{2}\end{array}$ & $\begin{array}{c}0.012^{* * *} \\
(0.004)\end{array}$ & & $\begin{array}{l}0.011^{\star *} \\
(0.004)\end{array}$ & & $\begin{array}{l}-0.015^{\star \star} \\
(0.007)\end{array}$ & $\begin{array}{l}0.012^{\star \star} \\
(0.005)\end{array}$ \\
\hline Cash crops (S2SLS) & & & & $\begin{array}{c}-0.0002 \\
(0.007)\end{array}$ & & \\
\hline Pubs, pth pop (1923) & & $\begin{array}{l}0.038^{\star \star \star} \\
(0.007)\end{array}$ & $\begin{array}{l}0.038^{\star \star \star} \\
(0.007)\end{array}$ & $\begin{array}{l}0.033^{\star \star \star} \\
(0.006)\end{array}$ & $\begin{array}{c}-0.0005 \\
(0.007)\end{array}$ & $\begin{array}{c}0.050^{\star \star \star} \\
(0.007)\end{array}$ \\
\hline Individual controls & yes & yes & yes & yes & yes & yes \\
\hline $\begin{array}{l}\text { Historical and geo } \\
\text { controls }\end{array}$ & yes & yes & yes & yes & yes & yes \\
\hline $\mathrm{FE}$ & $\begin{array}{l}\text { Country- } \\
\text { round }\end{array}$ & $\begin{array}{l}\text { Country- } \\
\text { round }\end{array}$ & $\begin{array}{l}\text { Country- } \\
\text { round }\end{array}$ & $\begin{array}{l}\text { Country- } \\
\text { round }\end{array}$ & $\begin{array}{l}\text { Country- } \\
\text { round }\end{array}$ & $\begin{array}{l}\text { Country- } \\
\text { round }\end{array}$ \\
\hline Ethnic stayer/leaver & Both & Both & Both & Both & Leaver & Both \\
\hline Mean dep. var. & 0.1314 & 0.1314 & 0.1314 & 0.1314 & 0.1226 & 0.13 \\
\hline Observations & 123,883 & 123,883 & 123,883 & 123,883 & 44,049 & 88,154 \\
\hline$R^{2}$ & 0.044 & 0.045 & 0.045 & 0.046 & 0.045 & 0.050 \\
\hline
\end{tabular}

\section{TABLE 2. Cultural Persistence in Ethnic Identity}

\begin{tabular}{|c|c|c|c|c|c|}
\hline & \multicolumn{5}{|c|}{ Ethnic-level: Ethnic vs. national identity } \\
\hline & \multicolumn{4}{|c|}{ All } & \multirow{2}{*}{$\begin{array}{c}\text { In bibliography } \\
\text { (5) }\end{array}$} \\
\hline & (1) & $(2)$ & (3) & $(4)$ & \\
\hline Cash crops, USD per $\mathrm{km}^{2}$ & $\begin{array}{l}-0.009 \\
(0.008)\end{array}$ & & $\begin{array}{l}-0.010 \\
(0.008)\end{array}$ & $\begin{array}{l}-0.007 \\
(0.010)\end{array}$ & $\begin{array}{c}0.019 \\
(0.017)\end{array}$ \\
\hline Pubs, pth pop (1923) & & $\begin{array}{l}0.010^{\star} \\
(0.005)\end{array}$ & $\begin{array}{l}0.010^{\star \star} \\
(0.005)\end{array}$ & $\begin{array}{l}0.016^{* * *} \\
(0.007)\end{array}$ & $\begin{array}{l}0.015^{\star} \\
(0.009)\end{array}$ \\
\hline Individual controls & Yes & Yes & Yes & Yes & Yes \\
\hline Historical and geo controls & No & No & No & No & No \\
\hline Fixed effect & Town & Town & Town & Town & Town \\
\hline Ethnic stayer/leaver & Both & Both & Both & Leaver & Leaver \\
\hline Mean dep. var. & 0.1314 & 0.1314 & 0.1314 & 0.12 & 0.12 \\
\hline Observations & 120,341 & 120,854 & 120,300 & 44,040 & 31,241 \\
\hline$R^{2}$ & 0.203 & 0.202 & 0.203 & 0.263 & 0.268 \\
\hline
\end{tabular}

\section{ANALYSIS II: ETHNIC BOUNDARY-MAKING}

We now turn to analyzing ethnic boundary-making operationalized through interethnic marriage. To measure ethnic exogamy, we take advantage of the couple recodes of the DHS household surveys, which capture self-reported ethnic identities of married couples. The empirical specifications are equivalent to the Afrobarometer-based geographic and cultural persistence models above, but now the unit of analysis is interviewed couple $i$ residing in location $\ell$ in country $c$ with spouses identifying with ethnic group(s) $e_{f}$ and $e_{m}$.

Knowing the appropriate match of practically all raw ethnic categories in DHS on the Ethnologue language tree allows us to analyze interethnic marriages at different levels of ethnolinguistic differentiation. ${ }^{32}$

\footnotetext{
${ }^{32}$ See Cervellati, Chiovelli, and Esposito (2018) for a similar approach.
} 


\section{FIGURE 3. Geographic Persistence: Cash Crops, Publications, and Ethnic Marriages}

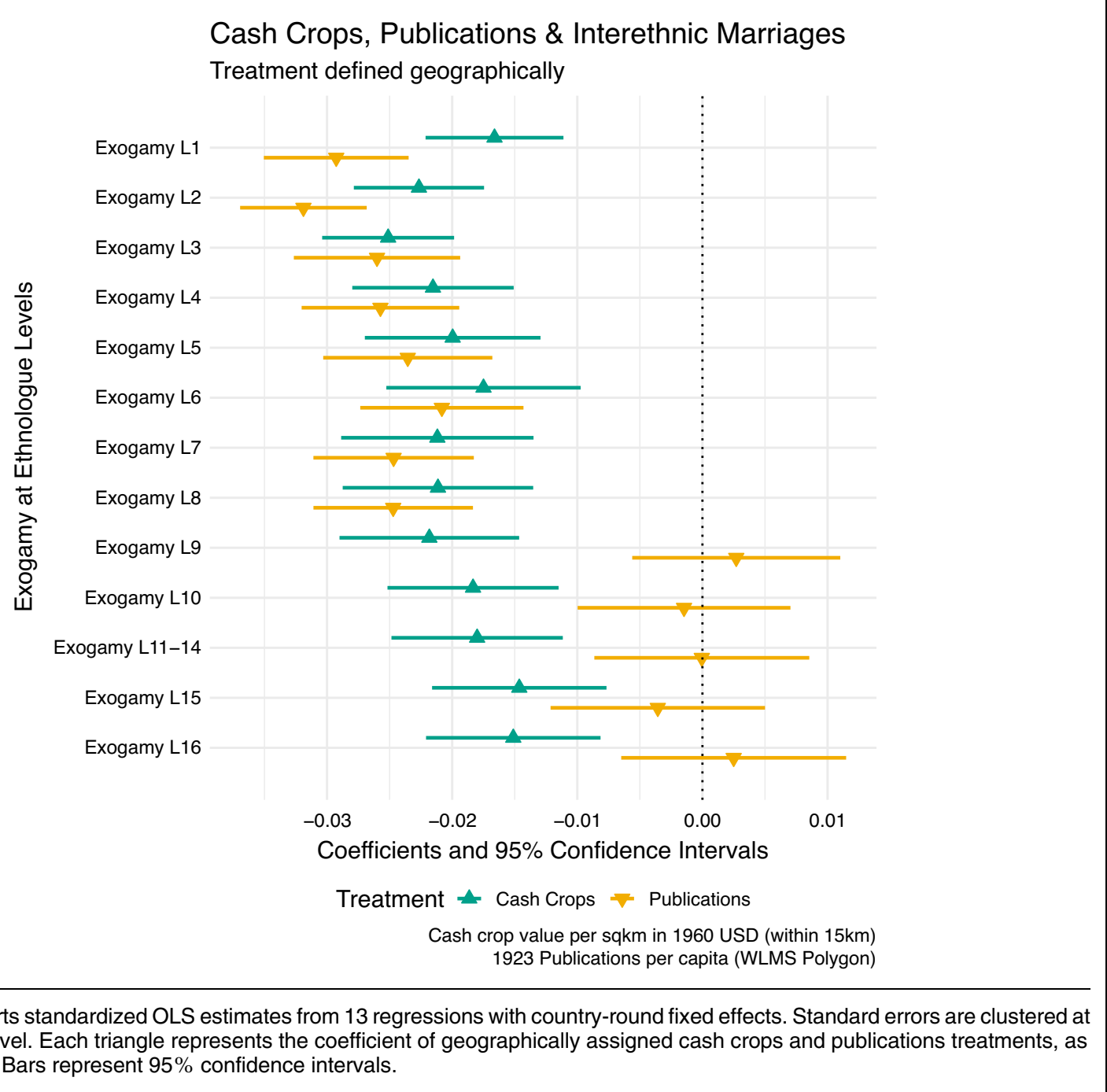

Ethnologue has 13 levels of language differentiation $d$ in our sample. Differentiation $d=1$ distinguishes broad language families, and as $d$ increases, more closely related ethnolinguistic categories are separated. We therefore define 13 binary outcome variables Sal iee $^{d}$, indicating whether the two spouses in respondent couple $i$ self-report belonging to different ethnic groups at level of differentiation $d$.

Two examples from Nigeria illustrate the operationalization of our interethnic marriage outcomes. A marriage between a female respondent identifying as Yoruba and a male Hausa respondent is coded as exogamous on all levels of the language tree. The Yoruba language belongs to the Niger-Congo language family, whereas Hausa is an Afro-Asiatic language. These language families are already separate on the first level, and therefore Yoruba and Hausa do not share any nodes on the language tree. In contrast, a Yoruba-Igala couple is coded as endogamous on levels 1-6 and as exogamous thereafter. The Yoruba and Igala languages share the first six nodes of the language tree but then branch out in different directions. 33

If cash crop agriculture sparked a process of more exclusionary identities, we would expect lower interethnic marriage rates at even the furthest branches of the language tree. A Yoruba respondent from a cash crop region would be similarly less likely to be married to a Hausa as to an Igala speaker. If print technologies led to salient but porous ethnic boundaries, we would expect members of these groups (e.g,. Yoruba) to be less likely to choose a spouse from a linguistically distant group (e.g., Hausa) but still open to intermarrying with linguistically related ethnic others (e.g., Igala). We test these hypotheses for both the geographic and ethnic definitions of our treatment, as defined above.

\footnotetext{
${ }^{33}$ Figures I.6 and I.7 in the SI schematically illustrate these examples.
} 


\section{FIGURE 4. Cultural Persistence: Cash Crops, Publications, and Ethnic Marriages}

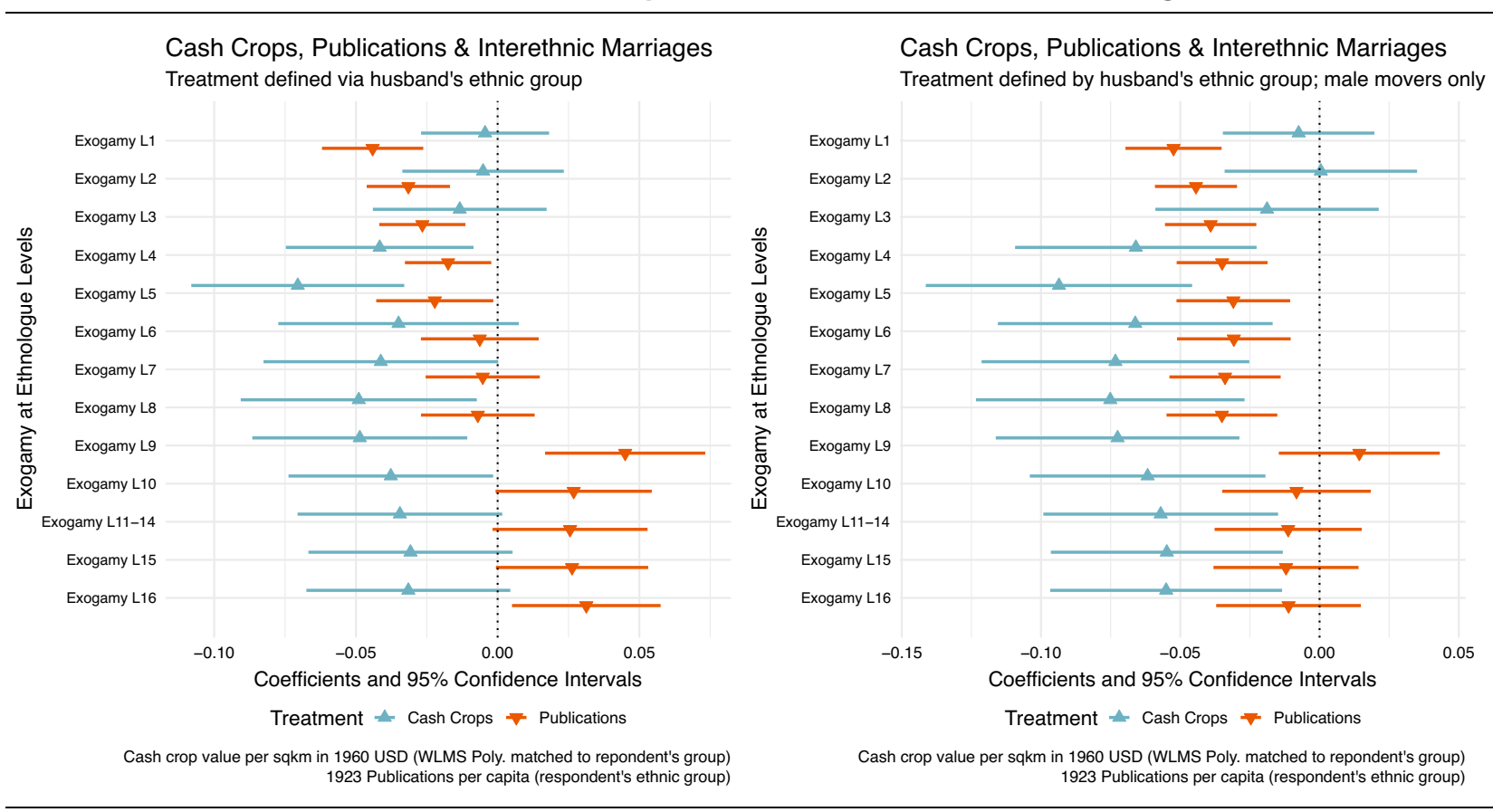

Note: Each triangle represents the standardized OLS estimates (beta coefficient) of ethnic-level cash crop and print technology treatments, as described in the text. The left panel is based on analyses of the whole sample, and the right pane/ reports results from models run on the subsample of ethnic movers only. Bars represent $95 \%$ confidence intervals.

\section{Geographic Persistence}

Figure 3 presents coefficient estimates from 13 models based on geographically assigned treatment variables. All 13 exogamy outcomes and both treatment variables are standardized to mean 0 and SD 1 to facilitate comparing coefficient sizes across Ethnologue levels and treatments. The cash crop coefficients in Figure 3 are consistently negative and significant across all linguistic levels of differentiation. Interethnic marriages are between 0.015 and 0.025 standard deviations less likely in locations with one-standard-deviation higher levels of late colonial cash crop production. While these effect sizes may appear small in standard-deviation terms, their coefficients are, again, similar in magnitude to contemporary modernization proxies such as education and formal employment. ${ }^{34}$ The coefficients on the publication variable are negative, significant, and somewhat larger in absolute size on levels 1-8 of the Ethnologue language tree. From level 9 onward, publication coefficients drop substantially and become statistically indistinguishable from zero. This pattern supports our theoretical conjecture that African-language printing heightened the salience of ethnic identities but, compared with cash crop agriculture, led to more porous boundaries and more assimilation among linguistically close ethnic categories. We show in the Appendix (Figure A6) that, similar to the Afrobarometer analysis

\footnotetext{
${ }^{34}$ See Appendix Tables A2-A5
}

above, these geographic effects are driven by ethnic stayers.

\section{Cultural Persistence}

Figure 4 summarizes results from models that assign treatment variables by husbands' ethnic identities and include location fixed effects. ${ }^{35}$ The left-hand panel reports findings from analyses of the entire sample of couples for which both spouses' ethnic identity was successfully matched to the Ethnologue language tree, whereas the right-hand panel restricts the sample to ethnic movers only and thus compares marital choices by husbands outside of their ancestral homeland. These within-location models yield results that are substantively similar to those from the geographic-persistence analysis above. Effect sizes and the level difference between historical cash crop production and African language publishing appear, if anything, to be more pronounced.

\section{ROBUSTNESS AND MECHANISMS}

The empirical results in previous sections suggest that (i) historical cash crop production and the uptake of print technologies increased groups' mobilizational capabilities and political relevance in the

\footnotetext{
${ }^{35}$ See Appendix Figure A7 for results when assigning treatments based on wives' ethnicities.
} 
postindependence period; (ii) these historical forces also have had persistent effects on individual ethnic salience but through different channels-cash crop effects appear tied to land and sites of historical cultivation and publishing effects stem from cultural transmission among members of the ethno-linguistic group; and (iii) we observe differential effects on interethnic marriage with linguistically proximate out-groups. Note that in contrast to the Afrobarometer models, we find cultural persistence (ethnic mover) effects of cash crops on ethnic marriages, suggesting perhaps that political ethnicity is easier to change than deep-rooted cultural norms about appropriate marital choices. ${ }^{36}$

In the remainder of this section, we summarize findings from our prespecified analyses to account for potential endogeneity before presenting additional specifications that address a series of potential alternative explanations that might account for the observed empirical patterns.

\section{Addressing Endogeneity}

Across most analyses, we address threats that the effects of historical cash crop production and vernacular language publishing are endogenous to underlying geographic factors or ethnic groups' precolonial characteristics. The effects of cash crops on group-level politicization (Figure 2) and interethnic marriages (Appendix Figure A4) are robust to instrumenting cash crop production with indicators of suitability in a spatial-2SLS setup. ${ }^{37}$ To account for potential selection of missionary and publishing activities into certain areas or groups, we show the results are robust to restricting the analysis to Ethnologue groups with a Christian mission (Figure 2) and publishing at the intensive margin (column 6 in Table 1; column 5 in Table 2; Figures A4 and A5). To address potential geographic confounders of publishing, the results presented in Table 2 and Figure 4 include location fixed effects. This increases our confidence that geographic confounders do not explain away exogamy patterns or cultural persistence in ethnic identity.

\section{Alternative Explanations}

\section{Group Size}

If larger groups were more likely to cultivate cash crops or have vernacular publications, our results may pick up their size-based advantages in coalition formation (Bates 1983; Posner 2005). We account for this issue in several ways. First, the publications treatment in the survey analyses is normalized by the number of

\footnotetext{
${ }^{36}$ This seems consistent with recent findings that local ethnic minorities face incentives to vote for the local majority candidate rather than one of their own (Ichino and Nathan 2013).

${ }^{37}$ Afrobarometer results disappear when using this approach. One explanation is the lower spatial coverage of Afrobarometer, which has less than half the number of unique survey locations than DHS. In addition, Afrobarometer was geocoded ex post and location coordinates are probably less accurate.
}

language speakers as estimated by Rowling and Wilson (1923). Second, we use the HYDE population rasters (Klein Goldewijk et al. 2017) to control for precolonial population per ethnic polygon across all three analysis sections (see above). As HYDE only imperfectly captures group-level population, Appendix Table B7 and Figure B8 add precolonial political centralization as a proxy for precolonial group size and political cohesion (Murdock 1967). Results remain generally robust to accounting for group size, although coefficients get significantly smaller in the group-level political relevance models with the HYDE control. ${ }^{38}$

\section{Colonizer Effects}

We also show that the effects of cash crop agriculture and publishing on ethnic politicization and marriage patterns are not mere artifacts of British indirect rule (Ali et al. 2019). The results are reported in section III.4 of our Supplementary Information. We do observe that former French colonies have either zero or dampened publication effects, perhaps a consequence of France's more hegemonic cultural and linguistic policies in its colonies (Albaugh 2014; Cogneau and Moradi 2014). These heterogeneous effects offer additional suggestive evidence of the importance of vernacular language standardization and its propagation through schools and churches as a key mechanism driving ethnic politicization.

\section{Mechanisms}

We run causal mediation models (Acharya, Blackwell, and Sen 2016) to gauge the mechanisms through which our historical treatments affect contemporary ethnic salience and exogamy. First, we observe that accounting for modernization proxies such as urbanization, education, and wealth does not explain our findings and, if anything, makes them stronger (Figures B12[a], B12[d], and B13). Second and in line with Cagé and Rueda (2016), political engagement and public sphere variables from Afrobarometer explain up to $17 \%$ of the publications effect. Finally, historical group-level advantages in secondary and higher education account for relatively large shares of the publishing effect on interethnic marriages (15-26\% in geographic models, $16-43 \%$ in ethnic specifications, see Figure B14). These results, while only suggestive, point to the roles of an early intelligentsia in constructing ethnic identities and of continued political engagement in maintaining them.

\section{Resource Types}

We expected cash crop agriculture to matter due to local ethnic competition for economic benefits and ethnic elites' and communities' strategic boundarymaking. This mechanism is unlikely to play out under

\footnotetext{
${ }^{38}$ Figures B10 and B11 further control for ethnic polygon area. Supplementary Information III.1.2 more closely investigates the relationship between group size and publications.
} 
European-owned plantation or settler agriculture, nor is it likely in mining regions where there were limited benefits for indigenous farmers or where the colonial state or concession companies regulated access. Consistent with this, we show in Supplementary Information III.5 that our results are mainly driven by smallholder crops predominantly cultivated by African farmers. The effects of historical plantation agriculture and mining are weaker or even point in the opposite direction.

\section{Diversity and Religion}

One concern about the interethnic marriage results is whether they merely reflect differences in local ethnic diversity. In Supplementary Information III.6, we account for or interact our treatments with local-level ethnic fractionalization scores. The cash crop effects are larger in ethnically diverse locations strengthening our confidence that ethnic competition rather than local-level ethnic homogeneity explains lower exogamy levels.

Another possibility is that the publishing measure is merely picking up the spread of Christianity, which may explain politicization or marital choices. To rule this out, we control for Christian population share in the group-level models, rerun all exogamy models with directed religious couple fixed effects, and use religious denomination dummies in mediation models. Results are nearly identical to those from our baseline analyses (Supplementary Information III.7).

\section{CONCLUSION}

Our analysis shows that Africa's contemporary ethnic landscape was at least partially shaped by the persistent effects of the cash crop and printing revolutions that spread from the nineteenth century onward. In line with our hypotheses, geographic variation in cash crop agriculture and the uneven diffusion of print technologies differentially increased groups' mobilizational potential and their capabilities to compete for state power after independence. Our analysis of individuallevel identity salience suggests that these two forces affected ethnicity through different channels-with cash crop effects on individual identity salience tied to historic agricultural zones and publishing effects transmitted culturally among language speakers even beyond their ethnic homeland. Beyond self-reported identity salience, we find that these socioeconomic transformations resulted in different patterns of interethnic marriage. Publishing contributed to the construction of more porous boundaries than cash crop agriculture, leading to comparatively higher rates of intermarriage with linguistically related out-group members. This points to important differences in boundary policing among politicized groups based on their historical exposure to commercial agriculture and print technologies.

In shedding light on these endogenous processes, we highlight key underlying factors that may confound analyses of contemporary ethnic politics - such as contestation over land and cross-cutting languages. ${ }^{39}$ These dynamics require greater attention among scholars of ethnic politics and conflict, especially in light of more recent waves of internal migration, climate change, and rising land pressures ${ }^{40}$ How these changes affect ethnic boundaries, not least between pastoral and agricultural groups, are important questions for future research.

Our findings also have important implications for understanding the effects of colonialism on ethnicity. Much existing scholarship emphasizes the top-down effects of colonial social engineering and indirect rule on ethnic politicization. ${ }^{41}$ In contrast, our analysis demonstrates the importance of broader social and economic forces, which preceded colonialism and were key drivers of it. Further, our findings suggest that colonialism did not uniformly mold or "fix" ethnic boundaries. Instead, identity (re)construction arose as much from the strategic actions of African farmers, landowners, and elites, as well as those of missionaries, culture brokers, and ordinary people, responding to opportunities and constraints brought about by economic and technological change in the nineteenth and twentieth centuries.

\section{SUPPLEMENTARY MATERIALS}

To view supplementary material for this article, please visit http://dx.doi.org/10.1017/S0003055421000782.

\section{DATA AVAILABILITY STATEMENT}

Research documentation and data that support the findings of this study are openly available at the American Political Science Review Dataverse: https://doi. org/10.7910/DVN/WQEQPN.

\section{ACKNOWLEDGMENTS}

For excellent research assistance at various stages of this project, we thank, from ETH-Zurich: Paola Galano Toro, Vanessa Kellerhals, Benjamin Füglister, Lukas Dick; from Witten/Herdecke University: Carlos Mairoce and Julian Seitlinger; from Oxford University: Sidhart Bhushan, and Hedda Roberts; and from William \& Mary: Layla Abi-Falah, Aaron Spitler, and Henry Young. Earlier versions of our research design were presented at WGAPE, LSE, March 2018; Annual Meeting of the American Political Science Association, Boston, September 2018; Princeton University Comparative Politics Colloquium, October 2018; Annual Meeting of the AEHN Bologna, October 2018. First results and early paper versions presented at the

\footnotetext{
${ }^{39}$ On these points, see respectively, Boone (2014) and Laitin (2000a).

${ }^{40}$ See Klaus (2020) for a recent such example.

${ }^{41}$ See for example Mamdani (1996) and Posner (2005) and more recently Ali et al. (2019), McNamee (2019), and Müller-Crepon (2020).
} 
Annual Meeting of the American Political Science Association, Washington DC, September 2019; Political Economy Workshop, Zurich, October 2019; Annual Meeting of the Swiss Political Science Association, February 2020; virtual APSA 2020; Zurich Workshop in Empirical Political Economy, September 2020; ASREC annual conference, November 2020; Leiden Workshop in Political Science, October 2020; Workshop on the Politics of Favoritism, ZEW Mannheim, February 2021. We are grateful to participants for their suggestions and feedback. Special thanks to three anonymous reviewers, Matthew Gichohi, Corinne Bara, Joan Ricart-Huguet, Leila Demarest, Dan Posner, Tim Phillips, Carl Müller-Crepon, and LarsErik Cederman for comments and discussions.

\section{FUNDING STATEMENT}

This research was generously supported by the Swiss National Science Foundation (grant \#P0EZP1_159076, Pengl) and the US National Science Foundation (award \#1628498, Roessler).

\section{CONFLICT OF INTEREST}

The authors declare no ethical issues or conflicts of interest in this research.

\section{ETHICAL STANDARDS}

The authors affirm that this research did not involve human subjects.

\section{REFERENCES}

Acharya, Avidit, Matthew Blackwell, and Maya Sen. 2016. "Explaining Causal Findings without Bias: Detecting and Assessing Direct Effects.” American Political Science Review 110 (3): 512-29.

Adebanwi, Wale. 2014. Yorùbá Elites and Ethnic Politics in Nigeria: Obáfemi Awólowo and Corporate Agency. Cambridge: Cambridge University Press.

Adediran, Biodum. 1984. "Yoruba Ethnic groups or a Yoruba Ethnic Group? A Review of the Problem of Ethnic Identification." África (São Paulo) 7 (7): 57-70.

Ahlerup, Pelle, and Ola Olsson. 2012. "The Roots of Ethnic Diversity." Journal of Economic Growth 17 (2): 71-102.

Ake, Claude. 1993. "What is the Problem of Ethnicity in Africa?" Transformation (22): 14-22.

Albaugh, Ericka A. 2014. State-Building and Multilingual Education in Africa. Cambridge: Cambridge University Press.

Ali, Merima, Odd-Helge Fjeldstad, Boqian Jiang, and Abdulaziz B Shifa. 2019. "Colonial Legacy, State-Building and the Salience of Ethnicity in Sub-Saharan Africa." The Economic Journal 129 (619): 1048-81.

Anderson, Benedict. 1983. Imagined Communities: Reflections on the Origin and Spread of Nationalism. London: Verso.

Asiwaju, Anthony Ijaola. 1984. Partitioned Africans: Ethnic Relations across Africa's International Boundaries, 1884-1984. London: C. Hurst.

Aydemir, Abdurrahman, and George J. Borjas. 2011. “Attenuation Bias in Measuring the Wage Impact of Immigration." Journal of Labor Economics 29 (1): 69-112.
Barth, Fredrik. 1969. Ethnic Groups and Boundaries: The Social Organization of Culture Difference. London: Allen and Unwin.

Bates, Robert H. 1974. "Ethnic Competition and Modernization in Contemporary Africa." Comparative Political Studies 6 (4): 457-84.

Bates, Robert H. 1983. "Modernization, Ethnic Competition, and the Rationality of Politics in Contemporary Africa." In State versus Ethnic Claims: African Policy Dilemmas, eds. Donald Rothchild and Victor A Olorunsola, 152-71. Boulder, CO: Westview Press.

Berry, Sara. 1993. No Condition is Permanent: The Social Dynamics of Agrarian Change in Sub-Saharan Africa. Madison: University of Wisconsin Press.

Betz, Timm, Scott J. Cook, and Florian M. Hollenbach. 2019. "Spatial Interdependence and Instrumental Variable Models." Political Science Research and Methods 8 (4): 646-61.

Birnir, Jóhanna K., David D. Laitin, Jonathan Wilkenfeld, David M. Waguespack, Agatha S Hultquist, and Ted R. Gurr. 2018. "Introducing the AMAR (All Minorities at Risk) Data." Journal of Conflict Resolution 62 (1): 203-26.

Birnir, Jóhanna K., Jonathan Wilkenfeld, James D. Fearon, David D. Laitin, Ted Robert Gurr, Dawn Brancati, Stephen M. Saideman, et al. 2015. "Socially Relevant Ethnic Groups, Ethnic Structure, and AMAR." Journal of Peace Research 52 (1): 110-15.

Boni, Stefano. 2006. "Indigenous Blood and Foreign Labor: The 'Ancestralization' of Land Rights in Sefwi (Ghana)." In Land and the Politics of Belonging in West Africa, eds. Richard Kuba and Carola Lentz, 161-86. Leiden, NL: Brill.

Boone, Catherine. 2014. Property and Political Order in Africa: Land Rights and the Structure of Politics. New York: Cambridge University Press.

Boone, Catherine. 2017. "Sons of the Soil Conflict in Africa: Institutional Determinants of Ethnic Conflict over Land." World Development 96: 276-93.

Burgess, Robin, Remi Jedwab, Edward Miguel, Ameet Morjaria, and Gerard i Miquel. 2015. "The Value of Democracy: Evidence from Road Building in Kenya." American Economic Review 105 (6): 1817-51.

Cagé, Julia, and Valeria Rueda. 2016. "The Long-Term Effects of the Printing Press in Sub-Saharan Africa." American Economic Journal: Applied Economics 8 (3): 1-31.

Caselli, Francesc, and Wilbur John Coleman. 2013. "On the Theory of Ethnic Conflict." Journal of the European Economic Association 11 (1):161-92.

Cervellati, Matteo, Giorgio Chiovelli, and Elena Esposito. 2018. "Bite and Divide: Ancestral Exposure to Malaria and the Emergence and Persistence of Ethnic Diversity in Africa." CEPR Working Paper 13437.

Ceuppens, Bambi, and Peter Geschiere. 2005. "Autochthony: Local or Global? New Modes in the Struggle over Citizenship and Belonging in Africa and Europe." Annual Review of Anthropology 34: 385-407.

Chandra, Kanchan. 2004. Why Ethnic Parties Succeed: Patronage and Head Counts in India. Cambridge: Cambridge University Press.

Chandra, Kanchan. 2006. "What is Ethnic Identity and Does It Matter?" Annual Review of Political Scienece 9: 397-424.

Chandra, Kanchan. 2012. Constructivist Theories of Ethnic Politics. New York: Oxford University Press.

Chaney, Eric. 2016. "Religion and the Rise and Fall of Islamic Science." Working Paper.

Chimhundu, Herbert. 1992. "Early Missionaries and the Ethnolinguistic Factor during the 'Invention of Tribalism'in Zimbabwe." The Journal of African History 33(1):87-109.

Cogneau, Denis, and Alexander Moradi. 2014. "Borders that Divide: Education and Religion in Ghana and Togo Since Colonial Times." The Journal of Economic History 74 (3): 694-729.

Cohen, Abner. 1969. Custom and Politics in Urban Africa: A Study of Hausa Migrants in Yoruba Towns. Oakland: University of California Press.

Colson, Elizabeth. 1971. "The Impact of the Colonial Period on the Definition of Land Rights." In Colonialism in Africa, 1870-1960: Profiles of Change, Vol. 3, ed. Victor Turner 193-215. London: Cambridge University Press.

Dunning, Thad, and Lauren Harrison. 2010. "Cross-Cutting Cleavages and Ethnic Voting: An Experimental Study of Cousinage in Mali." American Political Science Review 104 (1): 21-39. 
Eifert, Benn, Edward Miguel, and Daniel N. Posner. 2010. "Political Competition and Ethnic Identification in Africa." American Journal of Political Science 54 (2): 494-510.

Ekeh, Peter P. 1975. "Colonialism and the Two Publics in Africa: A Theoretical Statement." Comparative Studies in Society and History 17 (1): 91-112.

Ekeh, Peter P. 1990. "Social Anthropology and Two Contrasting Uses of Tribalism in Africa." Comparative Studies in Society and History 32 (4): 660-700.

Englebert, Pierre, Stacy Tarango, and Matthew Carter. 2002. "Dismemberment and Suffocation: A Contribution to the Debate on African Boundaries." Comparative Political Studies 35 (10): 1093-118.

Epstein, Arnold Leonard. 1958. Politics in an Urban African Community. Manchester: Manchester University Press.

Eyoh, Dickson. 1999. "Community, Citizenship, and the Politics of Ethnicity in Post-Colonial Africa." In Sacred Spaces and Public Quarrels: African Cultural and Economic Landscapes, eds. Paul Tiyambe Zeleza and Ezekiel Kalipeni, 271-300. Trenton, NJ: Africa World Press.

Falola, Toyin. 1999. Yoruba Gurus: Indigenous Production of Knowledge in Africa. Trenton, NJ: Africa World Press.

Fanon, Frantz. 1963. The Wretched of the Earth. London: Grove Press.

Fearon, James D. 1999. "Why Ethnic Politics and 'Pork' Tend to Go Together." Unpublished Manuscript. Stanford University. https:// web.stanford.edu/group/fearon-research/cgi-bin/wordpress/wpcontent/uploads/2013/10/Pork.pdf.

Fearon, James D. 2006. "Ethnic Mobilization and Ethnic Violence." In The Oxford Handbook of Political Economy, eds. Donald A. Wittman and and Barry R. Weingast, 852-68. Oxford: Oxford University Press.

Fearon, James D., and David D. Laitin. 2000. "Violence and the Social Construction of Ethnic Identity." International Organization 54 (4): 845-77.

Frankema, Ewout, Jeffrey Williamson, and Pieter Woltjer. 2018. “An Economic Rationale for the West African Scramble? The Commercial Transition and the Commodity Price Boom of 18351885." The Journal of Economic History 78 (1): 231-67.

Gellner, Ernest. 1983. Nations and Nationalism. Ithaca, NY: Cornell University Press.

Habyarimana, James, Macartan Humphreys, Daniel N. Posner, and Jeremy M. Weinstein. 2009. Coethnicity: Diversity and the Dilemmas of Collective Action. New York: Russell Sage Foundation.

Hale, Henry E. 2004. "Explaining Ethnicity.” Comparative Political Studies 37 (4): 458-85.

Hance, William A., Vincent Kotschar, and Richard J. Peterec. 1961. "Source Areas of Export Production in Tropical Africa." Geographical Review 51 (4): 487-99.

Hechter, Michael. 1978. "Group Formation and the Cultural Division of Labor." American Journal of Sociology 84 (2): 293-318.

Hill, Polly. 1963. The Migrant Cocoa-Farmers of Southern Ghana. Cambridge: Cambridge University Press.

Hirschman, Albert O. 1977. "A Generalized Linkage Approach to Development, with Special Reference to Staples." Economic Development and Cultural Change 25: 67-98.

Hogendorn, Jan S. 1969. "Economic Initiative and African Cash Farming: Pre-colonial Origins and Early Colonial Developments." In Colonialism in Africa, 1870-1960, Vol. 4, eds. Peter Duignan and Lewis H. Gann, 283-328. Cambridge: Cambridge University Press.

Hopkins, Anthony G. 1973. An Economic History of West Africa. New York: Columbia University Press.

Horowitz, Donald L. 1985. Ethnic Groups in Conflict. Oakland: University of California Press.

Ichino, Nahomi, and Noah L. Nathan. 2013. "Crossing the Line: Local Ethnic Geography and Voting in Ghana." American Political Science Review 107 (2): 344-61.

Jedwab, Remi, Felix zu Selhausen, and Alexander Moradi. 2018. "The Economics of Missionary Expansion: Evidence from Africa and Implications for Development." Unpublished Manuscript.

Kalyvas, Stathis N. 2008. "Ethnic Defection in Civil War." Comparative Political Studies 41 (8): 1043-68.
Klaus, Kathleen. 2020. Political Violence in Kenya: Land, Elections, and Claim-Making. New York: Cambridge University Press.

Klein Goldewijk, Kees, Arthur Beusen, Jonathan Doelman, and Elke Stehfest. 2017. "Anthropogenic Land Use Estimates for the Holocene: HYDE 3.2." Earth System Science Data 9 (2): 927-53.

Klein Goldewijk, Kees, Arthur Beusen, and Peter Janssen. 2010. "Long-Term Dynamic Modeling of Global Population and BuiltUp Area in a Spatially Explicit Way: HYDE 3.1." The Holocene 20 (4): 565-73.

Koter, Dominika. 2016. Beyond Ethnic Politics in Africa. New York: Cambridge University Press.

Kramon, Eric, Joan Hamory Hicks, Sarah Baird, and Edward Miguel. 2021. "Deepening or Diminishing Ethnic Divides? The Impact of Urban Migration in Kenya." American Journal of Political Science. https://doi.org/10.1111/ajps.12590.

Laitin, David D. 2000a. "Language Conflict and Violence: The Straw that Strengthens the Camel's Back." European Journal of Sociology (Archives Européennes de Sociologie) 41 (1): 97-137.

Laitin, David D. 2000b. "What is a Language Community?" American Journal of Political Science 44 (1): 142-55.

Laitin, David D. 2007. Language Repertoires and State Construction in Africa. New York: Cambridge University Press.

Laitin, David D., and Daniel Posner. 2001. "The Implications of Constructivism for Constructing Ethnic Fractionalization Indices." APSA-CP: Newsletter of the Organized Section in Comparative Politics of American Political Science Association 12 (1): 13-7.

Lentz, Carola. 2013. Land, Mobility, and Belonging in West Africa: Natives and Strangers. Bloomington: Indiana University Press.

Mamdani, Mahmood. 1996. Citizen and Subject: Contemporary Africa and the Legacy of Late Colonialism. Princeton, NJ: Princeton University Press.

Mann, Michael, and Valerie Sanders. 1994. A Bibliography of African Language Texts. London: Hans Zell Publishers.

Marshall-Fratani, Ruth. 2006. "The War of 'Who is Who': Autochthony, Nationalism, and Citizenship in the Ivoirian Crisis." African Studies Review 49 (3): 9-43.

McNamee, Lachlan. 2019. "Indirect Colonial Rule and the Political Salience of Ethnicity." World Development 122: 142-56.

Michalopoulos, Stelios. 2012. "The Origins of Ethnolinguistic Diversity." American Economic Review 102 (4): 1508-39.

Michalopoulos, Stelios, and Elias Papaioannou. 2013. "Pre-Colonial Ethnic Institutions and Contemporary African Development." Econometrica 81 (1): 113-52.

Miguel, Edward. 2004. "Tribe or Nation? Nation Building and Public Goods in Kenya versus Tanzania." World Politics 56 (3): 327-62.

Miles, William F. S., and David A. Rochefort. 1991. "Nationalism versus Ethnic Identity in Sub-Saharan Africa." American Political Science Review 85 (2): 393-403.

Müller-Crepon, Carl. 2020. "Building Tribes: How Administrative Units Shaped Ethnic Groups in Africa." Unpublished Manuscript. University of Oxford. http://www.carlmueller-crepon.org/ publication/admin_identities/CMC_BuildingTribes.pdf.

Müller-Crepon, Carl, Yannick I. Pengl, and Nils-Christian Bormann 2020. "Linking Ethnic Data from Africa." Unpublished Manuscript. ETH Zurich. https://yannickpengl.com/src/research/ ethnic matching.pdf.

Murdock, George Peter. 1959. Africa: Its Peoples and Their Culture History. New York: McGraw-Hill.

Murdock, George Peter. 1967. Ethnographic Atlas: A Summary. Pittsburgh, PA: University of Pittsburgh Press.

Nettle, Daniel. 1998. "Explaining Global Patterns of Language Diversity." Journal of Anthropological Archaeology 17 (4):354-74.

Nnoli, Okwudiba. 1978. Ethnic Politics in Nigeria. Enugu: Fourth Dimension Publishers.

Nnoli, Okwudiba. 1998. "Ethnic Politics in Africa: A Comparative Analysis." In Ethnic Conflicts in Africa, ed. Okwudiba Nnoli, 1-26. Dakar: CODESRIA.

Nunn, Nathan. 2008. "The Long-Term Effects of Africa's Slave Trades." The Quarterly Journal of Economics 123 (1): 139-76.

Nunn, Nathan, and Leonard Wantchekon. 2011. "The Slave Trade and the Origins of Mistrust in Africa." American Economic Review 101 (7): 3221-52.

Okoth, Assa. 2006. A History of Africa: African Nationalism and the De-Colonisation Process, Vol. 2. Nairobi: East African Publishers. 
Oucho, John O. 2002. Undercurrents of Ethnic Conflicts in Kenya. Leiden, NL: Brill.

Paine, Jack. 2019. "Ethnic Violence in Africa: Destructive Legacies of Pre-Colonial States." International Organization 73 (3): 645-83.

Parkin, Frank. 1974. "Strategies of Social Closure in Class Formation." In The Social Analysis of Class Structure, ed. Frank Parkin, 1-18. London: Tavistock Publications.

Peel, John David Yeadon. 2003. Religious Encounter and the Making of the Yoruba. Bloomington: Indiana University Press.

Pengl, Yannick I., Philip Roessler, and Valeria Rueda. 2021.

"Replication Data for: Cash Crops, Print Technologies and the Politicization of Ethnicity in Africa." Harvard Dataverse. Dataset. https://doi.org/10.7910/DVN/WQEQPN.

Posner, Daniel N. 2003. "The Colonial Origins of Ethnic Cleavages: The Case of Linguistic Divisions in Zambia." Comparative Politics 35 (2): $127-46$.

Posner, Daniel N. 2004a. "Measuring Ethnic Fractionalization in Africa." American Journal of Political Science 48 (4): 849-63.

Posner, Daniel N. 2004b. "The Political Salience of Cultural Difference: Why Chewas and Tumbukas are Allies in Zambia and Adversaries in Malawi." American Political Science Review 98 (4): $529-45$.

Posner, Daniel N. 2005. Institutions and Ethnic Politics in Africa. New York: Cambridge University Press.

Posner, Daniel N. 2017. "When and Why Do Some Social Cleavages Become Politically Salient Rather Than Others?" Ethnic and Racial Studies 40 (12): 2001-19.

Ranger, Terrence. 1989. "Missionaries, Migrants, and the Manyika: The Invention of Ethnicity in Zimbabwe." In The Creation of Tribalism in Southern Africa, ed. Leroy Vail, 118-50. Berkeley: University of California Press.

Robinson, Amanda Lea. 2014. "National versus Ethnic Identification in Africa: Modernization, Colonial Legacy, and the Origins of Territorial Nationalism." World Politics 66 (4): 709-46.

Rodney, Walter. 1972. How Europe Underdeveloped Africa. London: Bogle-L'Ouverture Publications.

Roessler, Philip. 2016. Ethnic Politics and State Power in Africa. New York: Cambridge University Press.

Roessler, Philip, Yannick I. Pengl, Robert Marty, Kyle Sorlie Titlow, Nicolas van de Walle. 2020. "The Cash Crop Revolution, Colonialism and Legacies of Spatial Inequality: Evidence from Africa." CSAE Working Paper WPS/2020-12.
Rothchild, Donald S. 1997. Managing Ethnic Conflict in Africa: Pressures and Incentives for Cooperation. Washington, DC: Brookings Institution Press.

Rowling, Frank, and Charles-Edward Wilson. 1923. Bibliography of African Christian Literature. London: Conference of Missionary Societies of Great Britain and Ireland.

Sasaki, Yu. 2017. "Publishing Nations: Technology Acquisition and Language Standardization for European Ethnic Groups." The Journal of Economic History 77 (4): 1007-47.

Simons, Gary F., and Charles D. Fennig. 2017. Ethnologue: Languages of the World. Dallas, TX: SIL.

Spear, Thomas T. 1997. Mountain Farmers: Moral Economies of Land \& Agricultural Development in Arusha \& Meru. Oakland: University of California Press.

Strommer, Martina A. 2015. "Imagined Communities, Invented Tribe? Early Missionary Language Documentation and the Creation of the Herero." In Colonialism and Missionary Linguistics, eds. Klaus Zimmerman and Birte KellermeierRehbein, 102-28. Berlin: De Gruyter.

Stryker, Sheldon. 1980. Symbolic Interactionism: A Social Structural Version. San Francisco: Benjamin-Cummings Publishing Company.

Usman, Aribidesi, and Toyin Falola. 2019. The Yoruba from Prehistory to the Present. New York: Cambridge University Press.

Vail, Leroy. 1989a. "Introduction: Ethnicity in Southern African History." Chap. 1 in The Creation of Tribalism in Southern Africa, ed. Leroy Vail. Oakland: University of California Press.

Vail, Leroy. 1989b. The Creation of Tribalism in Southern Africa. Oakland: University of California Press.

van den Berghe, Pierre L. 1981. The Ethnic Phenomenon. Amsterdam: Elsevier.

Vogt, Manuel, Nils-Christian Bormann, Seraina Rüegger, Lars-Erik Cederman, Philipp Hunziker and Luc Girardin. 2015. "Integrating Data on Ethnicity, Geography, and Conflict: The Ethnic Power Relations Data Set Family." Journal of Conflict Resolution 59 (7): 1327-42.

Weber, Eugen. 1976. Peasants into Frenchmen: The Modernization of Rural France, 1870-1914. Redwood City, CA: Stanford University Press.

Weber, Max. 1978. Economy and Society: An Outline of Interpretive Sociology, Vol. I. Oakland: University of California Press.

Wimmer, Andreas. 2013. Ethnic Boundary Making: Institutions, Power, Networks. Oxford: Oxford University Press.

Woodberry, Robert D. 2012. "The Missionary Roots of Liberal Democracy." American Political Science Review 106 (2): 244-74. 